\title{
AS ARMAS DOS TABOADA. APROXIMACIÓN A UNHA PECULIARIDADE HERÁLDICA DEZÁ
}

\author{
CÉSAR GÓMEZ BUXÁN
}

\begin{abstract}
Resumen
As armerías da liñaxe dos Taboada na antiga Terra de Deza amosan un feito diferencial con respecto ó resto de Galiza, adoptando non uns emblemas individuais, senón unha unión deles que se transmitiron de xeración en xeración. Neste artigo reflíctense, facendo un percorrido pola súa xenealoxía, as variacións que as armas da familia foron sufrindo ó longo dos séculos nesta comarca pontevedresa.
\end{abstract}

\section{Palabras Clave}

Taboada, heráldica, xenealoxía, Terra de Deza.

\begin{abstract}
The armories of the lineage of the Taboada in Deza's Former Earth show a differential fact with regard to the rest of Galicia, adopting not a few indivividual emblems, but an union of them that transmitted from generation to generation. In this article it is reflectet, doing a tour for his genealogy, the variations that the weapon of the family. They were suffering throughout the centuries in thos «region pontevedresa».
\end{abstract}

\section{Key Words}

Taboada, Heraldry, Genealogy, Terra de Deza. 
$\mathrm{A}$ riqueza heráldica de Galiza, tanto no seu aspecto cuantitativo como cualitativo, non deixa de sorprender ó curioso e ó investigador. Esta diversidade implica serias dificultades para o correcto estudio das armerías e a identificación das liñaxes representadas nos vellos escudos.

A situación vese agravada pola inexistencia duns catálogos ou tratados específicos que permitan o estudio deste patrimonio, en particular o da época medieval, variantes zonais e temporais e, porque non, diferentes interpretacións artísticas promovidas tanto polos fidalgos que encargaron o seu escudo como polos artesáns que plasmaron o proxecto nos diversos materiais. Ademais a lamentable falta de documentación e o elevado número de fidalgos que inzaron no rural galego, fan que sexa unha difícil tarefa o estudio a gran escala da heráldica galega, non xa como simple catalogación de pezas, senón o máis complicado, a investigación dos inicios da emblemática en Galiza e as correlacións entre liñaxes e as súas manifestacións armoriadas.

Como exemplo dunha peculiaridade nos deseños e composicións heráldicas, pódese cita-lo caso das armas dos Taboada na comarca de Deza (provincia de Pontevedra), unión de armerías que os diferencia das de outras zonas de Galiza e que nos ofrecen, en conxunto, interesantes informacións sobre a súa orixe e relacións familiares.

É coñecida a súa representación máis habitual: «De gules, catro paus recortados de ouro; bordura de prata, con oito caldeiras de sable». Os paus recortados podémolos denominar tamén táboas, xa que aluden directamente ó nome da liñaxe, constituíndose, pois, en «armas parlantes». Como curiosidade, pódense cita-las variacións que figuran en case tódolos nobiliarios desde o século XVI e nalgunha representación heráldica ${ }^{1}$, nas que se inclúen, substituíndo ás táboas polas comúns mesas de catro pés, que non teñen nada que ver coas primitivas representacións das armas dos Taboada ${ }^{2}$.

Nembargantes, na comarca dezá só en contadas ocasións (máis modernas, do século XVIII), figuran representadas as armas típicas. O corrente é atopar un conxunto de emblemas doutras liñaxes que conforman unha unidade transmitida en xeracións sucesivas da mesma familia.

\footnotetext{
' Por exemplo a existente na igrexa de Santa María a Real de Cesuris (Manzaneda). VEGA PATO, Tomás: Labras heráldicas en Terra de Trives. Museo Arqueolóxico Provincial de Ourense. Ourense, 2002, pp. 86-89.

${ }^{2} \mathrm{O}$ erro procede, seguramente, do descoñecemento do idioma e a vida do galego, pois aínda nos nosos tempos os bancos das antigas cociñas, formados por unha única táboa con pés nos extremos, reciben o nome de mesas.
}

Cuadernos de Estudios Gallegos, Tomo LIl, Fascículo 118, Santiago 2005. (Págs. 389 - 426) 


\section{OS TABOADA}

Primeiro, para comprende-la súa heráldica, é axeitado ofrecer unha perspectiva da xenealoxía desta fídalga familia asentada desde a Idade Media na comarca dezá.

O estudio desta familia nas súas orixes é complicado, tanto pola falta de documentación, como pola existencia de dúas liñas ou liñaxes diferenciados xa desde antigo, aínda que, como se verá máis adiante ó tratar da heráldica, se intúe unha relación entre os que habitaron en Deza e a coñecida familia do pazo de Bembibre e castelo de Castro Candad.

Un dos documentos máis interesantes sobre o particular é a carta denominada «Tocante a los Hixosdalgo», datada no $1603^{3}$, na que Manuel de Toubes, pertencente a esta liñaxe e señor do couto de Cristimil, comunica a un destinatario descoñecido pormenores sobre a fidalguía de Deza, cun especial tratamento da familia á que pertencía, os Taboada. No seu texto mestúranse elementos probados de xeito documental con outros que posiblemente se transmitiran oralmente xeración tras xeración. Sobre a súa orixe alúdese á disputa entre os Taboada de terras lucenses e os de Deza «los de la cassa de tauoada dizen que nosotros benimos de su cassa y nosotros decimos que ellos bienes de la nuestra que es el paco do cello sita en la feligresia de san martino do cello mas de trecientos anos a questa hes casa» ${ }^{4}$. Lamentablemente, non temos constancia documental da existencia do solar do Cello, nin tampouco dos primeiros posuidores que cita Manuel de Toubes, Gonzalo Taboada, señor do pazo do Cello sobre o 1400, e o seu fillo Vasco Taboada, pertegueiro na terra de Deza pola igrexa de Santiago.

Cita ademais a existencia doutros individuos deste apelido «ai otra linaxe de tauoadas en esta tierra son naturales y su casa la tubieron arimada a la yglesia de tauoada $)^{5}$.

Por eses anos finais do século XV aparecen residindo en Deza outros personaxes con este apelido, pero non pertencentes á liñaxe. Son, por exemplo, Roi Taboada,

\footnotetext{
${ }^{3}$ RUBIA ALEJOS, F. e GÓMEZ BUXÁN, C.: «Tocante a los Hixosdalgo. Carta de Manuel de Toubes, genealogista dezano del siglo XVIII», Anuario de Estudios e Investigación Descubrindo, $\mathrm{n}^{\circ}$ 2 , ano 2000 , pp. 7-62.

${ }^{4}$ Non temos constancia de ningunha edificación en San Martiño do Cello que responda a estas características. O lugar de Pazos, en San Martiño do Cello e San Xoán de Palmou si puidera ter unha orixe medieval, pero non como solar dos Taboada, familia que está ben documentada en terras lucenses, na comarca homónima.

${ }^{5}$ Proceden do lugar e parroquia homónima de Santiago de Taboada (concello de Silleda).
} 
que recibiu varios foros de Oseira ${ }^{6}$, ou Lorenzo Taboada, ascendente dos posuidores da casa de Barcia, que vivía en Deza polo 1460.

\section{HERÁLDICA NO SÉCULO XV}

O estudio das armas relativas a este apelido nas labras heráldicas da comarca de Deza deixa clara unha relación entre a maior parte delas. No tocante ós máis antigos exemplos desta zona, é curiosa a súa similitude con outras pezas dispersas pola xeografía galaica, en concreto cos sepulcros da casa de Taboada que aínda se conservan na igrexa de Ferreira de Pallares (concello de Guntín), datados no século $\mathrm{XV}^{7}$. Estes representan unha forma anterior á empregada comunmente, xa fusionada, de táboas e caldeiros ${ }^{8}$.

Nestes sepulcros pódese ollarunha serie de pedras armeiras que, conxuntamente, establecen unha relación senón real si de facto na evolución das armerías dos Taboada. Sitúanse en dous conxuntos funerarios anepígrafes datados no século $\mathrm{XV}$, emprazados cada un nun arcosolio gótico. Un corresponde a un cabaleiro e o outro a unha dama, ámbolos dous da familia dos Taboada e moi posiblemente marido e muller. No frontal de ámbolos dous dispóñense tres escudos e na parede do fondo do lucilo sepulcral outras dúas pedras armeiras en cada un.

Estas armerías do fondo do lucilo semellan máis antigas que as dos frontais dos sepulcros. No do cabaleiro o primeiro escudo trae cinco caldeiras e o segundo un pau (Figura 1). No da dama, o primeiro trae trece roeis en tres pales e o segundo un pau.

Pasando xa ás labras heráldicas do frontal dos sepulcros, e como evolución e unión nunha soa labra destas dúas representacións, se pode citar outra das armerías, cuartelada en cruz, a central do monumento do cabaleiro. No primeiro cuartel trae tres caldeiras, mobles que se repiten no cuarto cuartel (neste caso só dúas caldeiras, ben por analoxía coa representación citada anteriormente, ou por aco-

\footnotetext{
${ }^{6}$ Por exemplo no 1480 o lugar de Agruchave da Cima, e no 1481 o foro ó dito Rui Taboada e á súa muller Aldonza González o casal de Pazo, en San Martiño de Lalín. PORTELA, Ma José et al.: Catálogo del Archivo Monacal de Oseira en 1629. Tórculo Edicións, 1993, pp. 149 e ss.

${ }^{7}$ CHAMOSO LAMAS, Manuel: Escultura funeraria en Galicia. Instituto de Estudios Orensanos «Padre Feijoo». Ourense, 1979, pp. 268-275.

${ }^{8}$ A fusión de armería está extensamente estudiada, e este caso en particular, polos recoñecidos heraldistas D. Eduardo Pardo de Guevara y Vaidés e D. Xosé Antón García González-Ledo na obra Palos, fajas y jaqueles. La fusión de armerias en Galicia durante los siglos XIII al XVI. Servicio de Publicacións. Deputación Provincial de Lugo. 1997.
} 

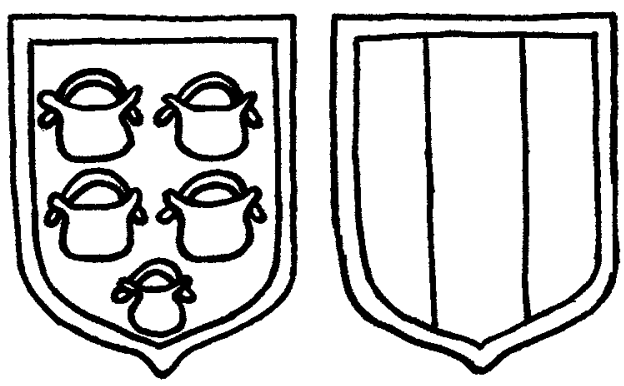

Figura 1.

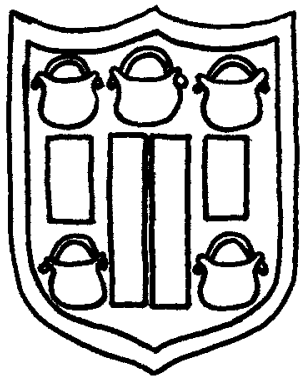

Figura 3.

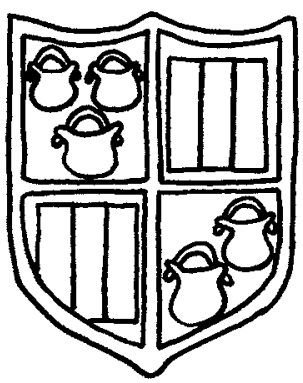

Figura 2.

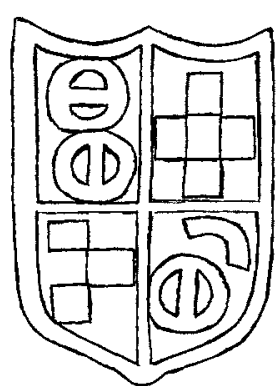

Figura 4.

modación ó espacio do citado cuartel). Nos cuarteis segundo e terceiro repítense tres táboas (Figura 2).

Noutra das labras (a da cabeceira do frontal da dama) figura xa unha forma fusionada de xeito parcial, con catro táboas (as laterais máis curtas), tres caldeiras en xefe e dúas nos cantóns da punta (como vemos, tamén cinco, tal e como figuran nas outras dúas labras) (Figura 3).

Outra delas (na cabeceira do frontal do cabaleiro), tamén cuartelada en cruz, trae no primeiro cuartel dúas rodas de carro en $\mathrm{pal}^{9}$, no segundo un xaquelado, no terceiro outro xaquelado e no cuarto unha roda de carro superada dunha camba ${ }^{10}$ (Figura 4).

${ }^{9}$ Os eixes das rodas están xirados $90^{\circ}$, por motivos estéticos, quizais, pero tamén se repite esta disposición nas pedras armeiras da comarca de Deza, como despois veremos, copia fiel destas labras, ou ten outro significado?

${ }^{10}$ Como no primeiro cuartel deberían aparecer dúas rodas de carro, pero a menor superficie útil fai que se simplifique unha das rodas poñendo só unha parte da mesma (unha camba, como se denomina cada unha das dúas pezas que conforman a estructura exterior da roda). 
Igualmente relativo ós Camba é outro escudo que trae, nun só campo, catro rodas de carro en $\mathrm{cruz}^{11}$, acompañadas de cinco cambas, dúas nos cantóns do xefe e tres na punta (Figura 5), emprazado no centro do frontal do sepulcro da dama.

Así mesmo, hai outras labras heráldicas, unha delas cos trece roeis dos López de Lemos (a dos pés da dama).

Como se verá nas páxinas sucesivas, estas representacións figuran tamén nas armerías da terra de Deza, polo que aínda ten máis forza a hipótese dunha relación, ben de parentesco ou de dependencia cos Taboada que tantas veces figuran nos feitos de armas do século XV galego.

\section{HERÁLDICA DOS TABOADA EN DEZA}

\subsection{Primeiras manifestacións}

As representacións heráldicas quizais máis primitivas da comarca de Deza coas armas da liñaxe dos Taboada ${ }^{12}$ son as existentes no pazo de Beilás (San Miguel de Goiás - Lalín) ${ }^{13}$.

O máis antigo ou, polo menos, sinxelo, é o testemuño conservado no lintel dunha porta, sobre mochetas decoradas. Atopamos gravado con liñas incisas unha roda de carro coas cambas ben marcadas, flanqueada de dous escudiños ${ }^{14}$. Alude esta representación ós Camba, familia desde antigo relacionada cos Taboada e que figuran unidas en moitas pedras armeiras (Figura 6).

O segundo exemplo no mesmo pazo é unha lumieira armoriada ${ }^{15}$ situada a uns cinco metros de altura (Figura 7), difíciles de apreciar, non tanto pola altura coma polo mal estado tanto da cubrición, xa caída e cuberta de vexetación, como das paredes da construcción. Nela hai tres pequenos escudos datables no primeiro cuarto do século XVI (Figura 8).

\footnotetext{
"É de notar tamén as orientacións dos eixes das rodas de carro.

${ }^{12}$ E das máis antigas en xeral, pois poucas son as labras heráldicas anteriores ó século XVI que se conservan en Deza.

${ }^{13}$ O pazo de Beilás, hoxe en ruínas, foi residencia dos Varela desde comezos do século XVI. Inserida no edificio aínda se conserva a torre que foi xerme do pazo, con interesantes elementos arquitectónicos, como unha porta de arco de medio punto, e outra de arco conopial. Foi publicado por RUBIA ALEJOS, F. e GÓMEZ BUXÁN, C.: «Beilás, lenta agonía pacega», en La Voz de Galicia, ed. Deza-Tabeirós, 8 de outubro de 2000, pp. 4-5.

${ }^{14}$ A erosión non permite apreciar se no campo había algo ben pintado ou labrado.

15 Fermoso termo suxerido polo recoñecido heraldista don Xosé Antón García González-Ledo, ó que expresamos a nosa gratitude tanto polos seus sempre atinados comentarios e apreciacións, como polo desinteresado ofrecemento dos seus debuxos para ilustrar estas páxinas.
} 


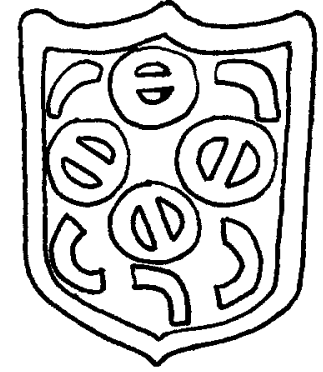

Figura 5.

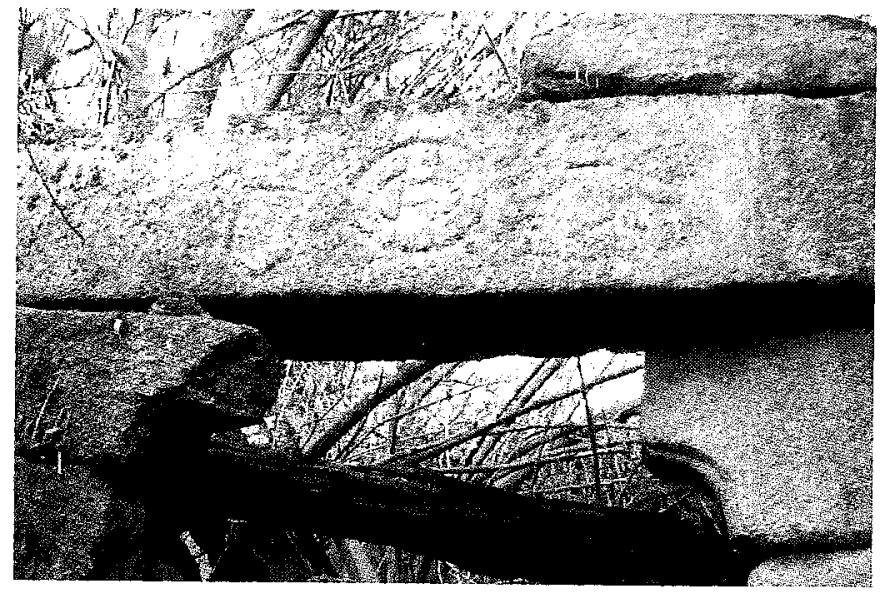

Figura 6.

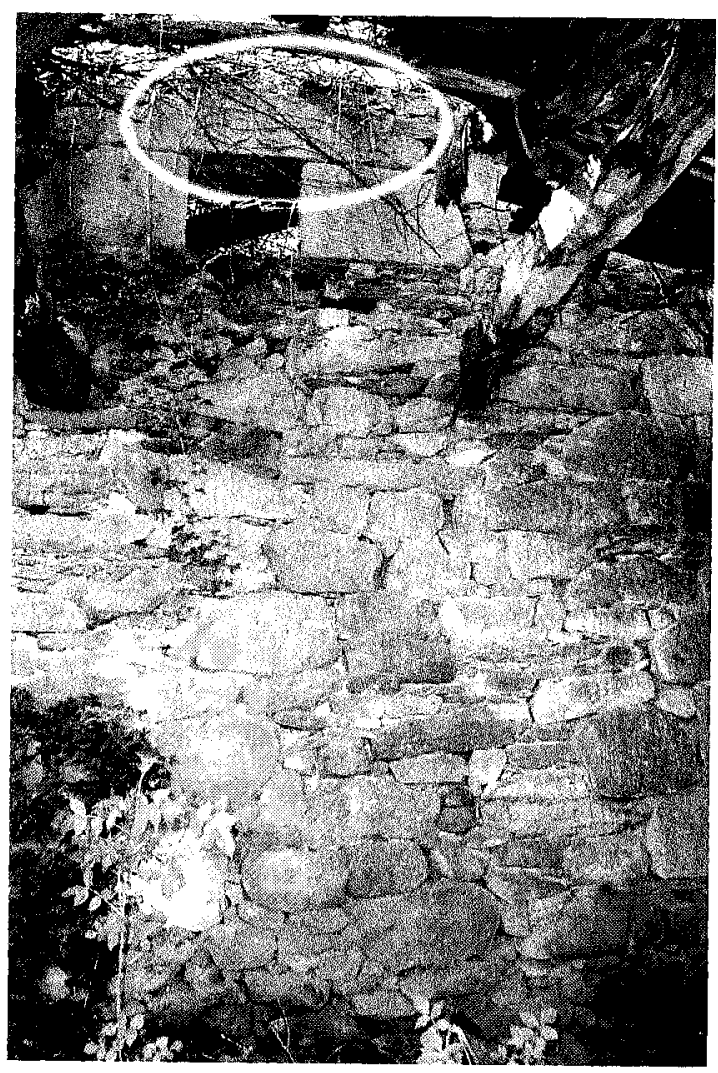

Figura 7.

Cuadernos de Estudios Gallegos, Tomo LII, Fascículo 118, Santiago 2005. (Págs. 389 - 426) 


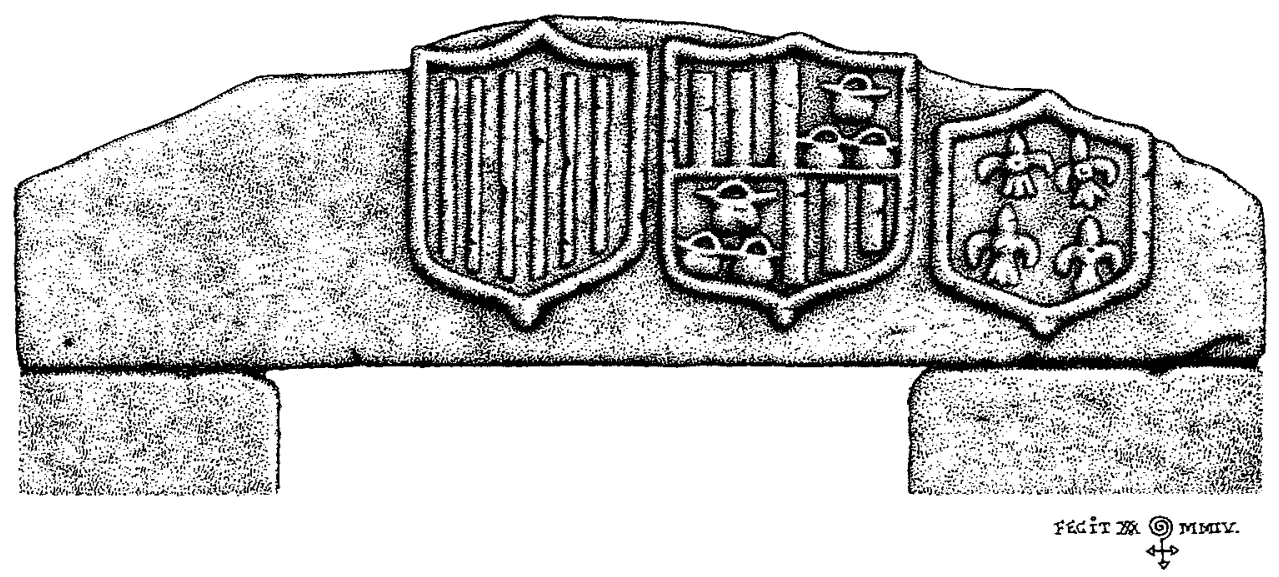

Figura 8. (Debuxo Xosé Antón García González-Ledo).

O central, de maior tamaño e quizais relativo á liñaxe principal, é cuartelado en cruz, e trae no primeiro e terceiro cuarteis tres caldeiras mal ordenadas, e nos cuarteis segundo e terceiro tres táboas en pal ${ }^{16}$, armas alusivas ós Taboada.

O da dereita do observador trae nun só campo catro flores de lis e o da esquerda seis varas.

O escudo principal, dos Taboada, recorda ós da igrexa de Ferreira. Os outros dous posiblemente se refiran á liñaxe dos Varela, moi estendidos pola comarca de Deza e as terras limítrofes. As coñecidas varelas remiten a esta familia, así como as flores de lis, nunha representación antiga, xa que a máis habitual en séculos posteriores é a unión nun só campo das cinco varelas, flores de lis (normalmente tres) e a roda de Santa Catalina, así como unha torre nos Varela de Dubra, engadindo bordura con cadea pechada en punta con cadeado ${ }^{17}$.

Facendo un pequeno inciso, podemos ofrecer varios exemplos de representación das armas dos Varela, tanto da comarca como doutras zonas de Galiza:

- Figura 9. Pedra armeira do pazo de Traspenas, en Santalla de Artoño (Agolada). Forma ovalada rematada en punta nos extremos superior e inferior. Cuartelada en cruz coa roda de Santa Catalina, cinco lises en aspa, as

\footnotetext{
${ }^{16}$ A erosión e o pequeno tamaño destes tres escudos dificulta a visión das tres táboas nos cuarteis segundo e terceiro, o interior sumado á división do cuartel.

${ }^{17}$ Arrinca estra tradición da lenda que atribúe a personaxes desta liñaxe a participación na victoria das Navas de Tolosa (ano 1212), na que tantas familias engadiron ás súas armas as cadeas.
} 


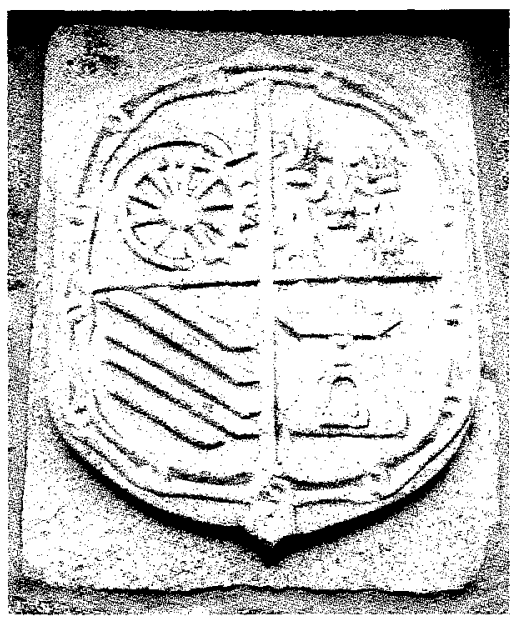

Figura 9.

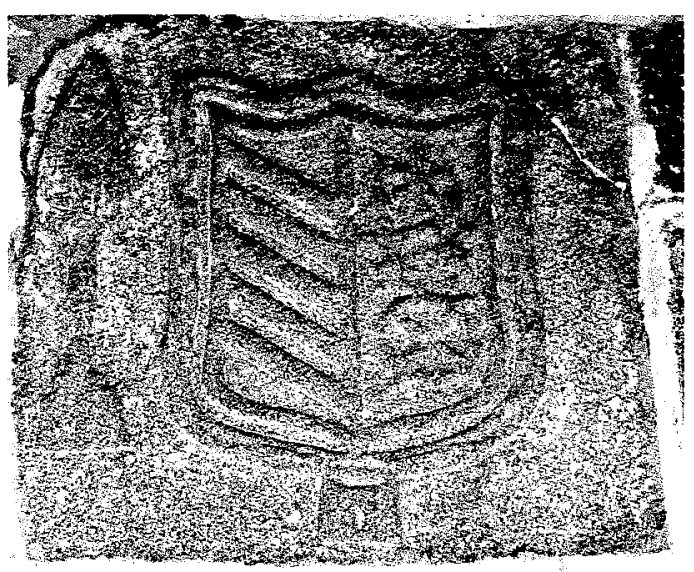

Figura 10.- (Fotografía Luis Couto Lorenzo).

cinco varelas e a torre almenada, así como a bordura de cadea pechada en punta con cadeado, todas elas armas relativas ós Varela.

- Figura 10. Un dos escudos da casa de Ramil, en San Martiño do mesmo nome (concello de Agolada). Con escotaduras na parte superior e contera, $o$ seu campo é partido. Trae no primeiro cuartel cinco varelas e no segundo cuartel unha roda de Santa Catalina superada de tres flores de lis mal ordenadas. Rodea ó escudo cadea pechada en punta con cadeado. Á destra unha figura que puidera ser unha árbore, quizais o piñeiro que faría referencia á liñaxe homónima e á súa relación cos Varela da Casa de Ramil ${ }^{18}$.

- Figura 11. Labra heráldica procedente dunha casa derrubada hai anos e colocada no mesmo lugar polo propietario, en Sada de Enriba. Escudo cuadrilongo sobre cartela e timbrado de elmo (a altura total é de $150 \mathrm{~cm}$ ). O seu campo é partido:

$1^{\circ}$. Cortado e medio partido (VARELA):

1-1. Unha torre donxonada de dous corpos adestrada de tres flores de lis en pal.

1-2. Cinco barras ou varelas.

1-3. Unha roda de Santa Catalina.

Bordura de cadea pechada con cadeado.

${ }^{18}$ GARCÍA GONZÁLEZ-LEDO, X.A.: Heráldica de Abegondo. 1994, pp. 151-169. 
$2^{\circ}$. Tres pombas pousadas sobre nubes (SEIXAS).

- Figura 12. Pedra armeira da casa de Quindimil (Palas de Rei-Lugo). Segundo don Xosé Antón García González-Ledo, polo ano 1982 situada na fachada dunha cafetería da Marina, na cidade da Coruña. Na actualidade arrombada nun almacén.

Representa, en conxunto as armas dos Varela. No seu campo vense as cinco varelas características da liñaxe, acompañadas no cantón destro do xefe de dúas flores de lis, e no cantón sinistro da punta de dúas medias rodas de Santa Catalina e outra flor de lis. Rodéao cadea con grosos elos, que debía estar pechada con cadeado (debeu rachar co traslado da pedra, así como parte da decoración de cordón que enmarca o escudo).

Volvendo ó pazo de Beilás, dicir que a colocación de ámbalas dúas pezas, a lumieira armoriada e o lintel coa roda de carro parece a orixinal, non na antiga torre (que polos elementos que conserva debe datar de finais do século XV ou comezos do XVI), senón nunha edificación lateral, con paredes de cachotería e mampostería, na que tamén están emprazadas as outras dúas pedras de armas da casa $^{19}$.

Por outra banda, no que atinxe á súa historia, o pazo de Beilás estivo ligado ata finais do século XIX ós Varela, pero non consta un parentesco antigo cos Taboada. Estes últimos si mantiñan una estreita relación coa parroquia de San Miguel de Goiás, pois no interior da súa igrexa, como se verá en páxinas sucesivas, foron enterrados os primeiros representantes da liñaxe e nesta freguesía tiña unha torre Gómez Taboada, «escudeiro», na que vivía no 1528 e $1532^{20}$. Posiblemente esteamos a falar da mesma construcción, que pasaría no segundo cuarto do século XVI á propiedade do escribán Lopo Varela, ben por venda ou foro.

\subsection{As armas de Gómez Taboada}

O seguinte paso na evolución das armerías dos Taboada en Deza arrinca na mesma parroquia de Goiás. No interior da igrexa parroquial atopamos un sepulcro con estatua xacente datable nos últimos anos do século XV ou na primeira década do XVI. Foi feito por Gómez Taboada, e nel foi enterrado, así como varios dos

${ }^{19}$ Xa máis modernas, unha delas relativa ós Salgado e outra ós Varela.

${ }^{20}$ Segundo datos existentes no Arquivo Histórico Universitario de Santiago (AHUS), Clero, San Martín, 471. Este Gómez Taboada, aínda que se repite este nome en varias xeracións da familia, debía se-lo fillo de Álvaro Taboada, señor do couto de Cristimil, que pasaría a habitar anos máis tarde no pazo de Liñares, en San Martiño de Prado. 


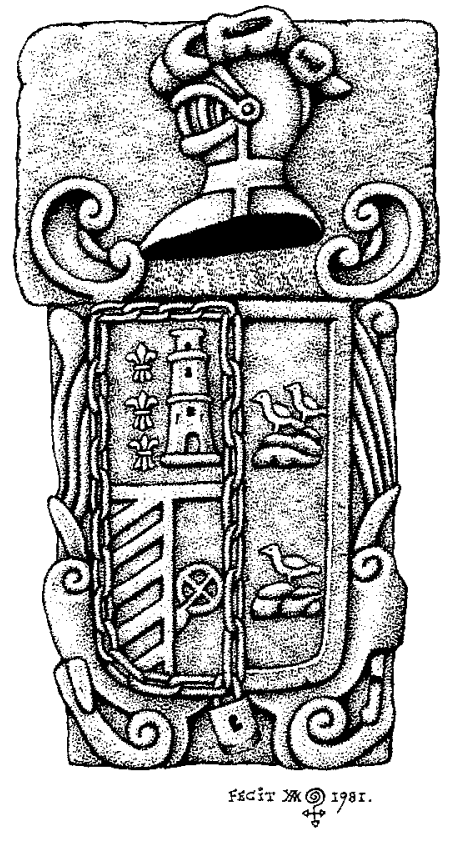

Figura 11.- (Debuxo Xosé Antón García González-Ledo).

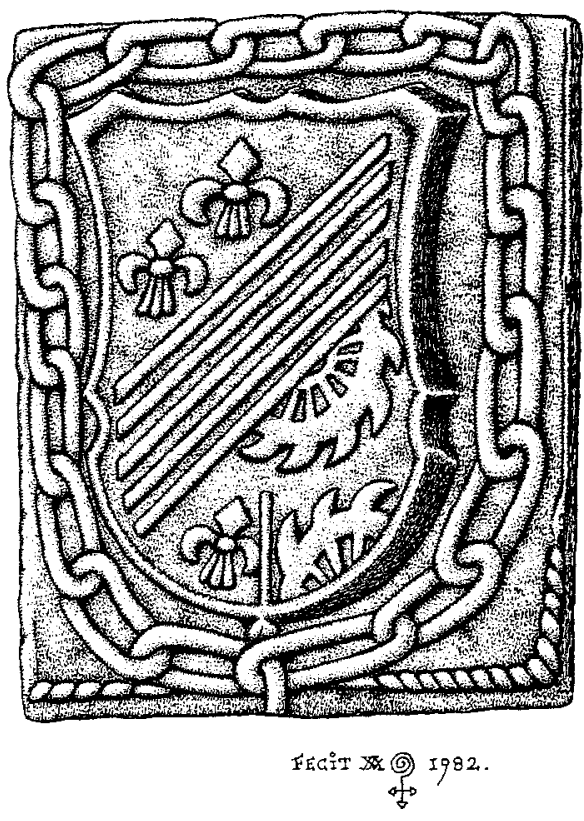

Figura 12.- (Debuxo Xosé Antón García González-Ledo).

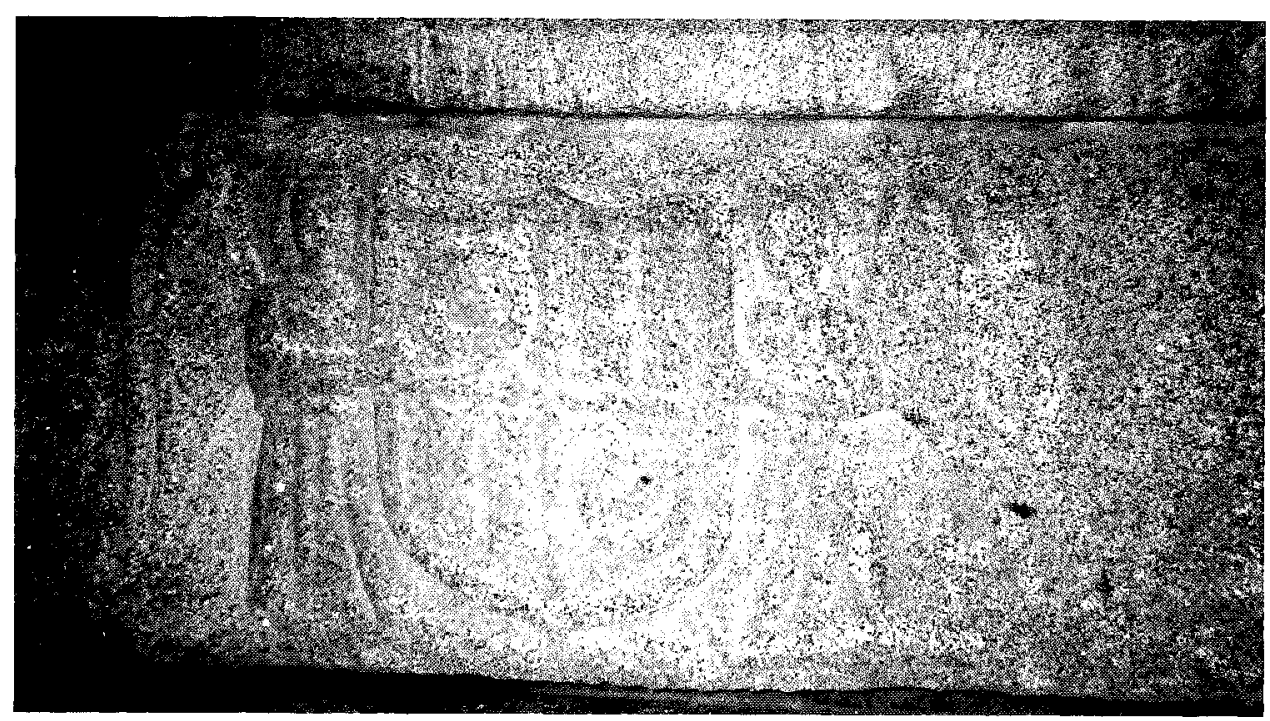

Figura 13. 
seus descendentes ${ }^{21}$. No frontis, un escudo de feitura antiga, con escotaduras na parte superior e contera na inferior, con anxos tenantes. No seu campo, cuartelado en cruz, figuran no primeiro e cuarto cuarteis unha roda de carro $^{22}$, e nos cuarteis segundo e terceiro dúas táboas, armas alusivas ós Taboada e Camba (Figura 13).

$\mathrm{Na}$ parroquia de San Xurxo de Cristimil consérvase aínda o testemuño dunha antiga construcción fidalga. No lintel dunha das súas portas atopamos unha labra heráldica contemporánea da de Goiás e coas mesmas armas, parcialmente obstaculizada a súa visión por unha chapa metálica que fai as veces de soportal para protexe-la porta de entrada da chuvia (Figura 14).

E non remataremos este epígrafe sen citar un exemplo existente na parroquia de San Martiño do Cello. A súa feitura, moi sinxela, mediante liñas incisas, non ofrece datos para a súa datación. O soporte, un sillar procedente doutra construcción anterior e trasladado a mediados do século XX ata o emprazamento actual, sen máis dato ${ }^{23}$. As armas, como as anteriores, rodas de carro e táboas postas en faixa, mantendo a peculiaridade da rotación dos eixes, o que nos leva a supoñer que se trata dunha labra orixinal, ou ben copia doutra máis antiga (Figura 15).

Gómez Taboada, chamado «Ceita Magadeus» ${ }^{24}$, do que rematamos de falar, era señor do couto de Cristimi ${ }^{25}$ e do castelo de Vilaboa ${ }^{26}$. É o primeiro desta estirpe do que temos verdadeira constancia documental. No 1444 un personaxe homónimo, que pensamos debería se-lo mesmo, figura recibindo en foro o couto de San Xurdo e o lugar de Cristimil do mosteiro de Toxos Outos ${ }^{27}$. Posuía Gómez Taboada moitos lugares e casares en Deza, constituíndose como un dos fidalgos máis im-

\footnotetext{
${ }^{21}$ Como acontecía e acontece, non se trataba dun monumento funerario individual, senón patrimonial dunha familia. Estes enterramentos eran construídos, en moitas ocasións, polos herdeiros do defunto, pero neste caso sabemos que o propio Gómez Taboada o mandou construír e polo menos dous dos seus descendentes (o seu fillo e o seu neto) ordenan nos seus testamentos ser enterrados en San Miguel de Goiás. Arquivo Pazo de Donfreán.

${ }^{22} E$ de destacar, como xa dixemos, que na maioría das representacións antigas destas armas as rodas de carro figuran rotadas unha con respecto á outra nun ángulo de $90^{\circ}$.

${ }^{23}$ Referencias orais recollidas do propietario actual do edificio, don José Cacheda Silva.

${ }^{24}$ Segundo se denomina na citada carta Tocante a los Hixosdalgo.

${ }^{25} \mathrm{O}$ couto de Cristimil era o centro e a orixe do poder dos Taboada na comarca dezá e nel tiñan xurisdicción e residencia.

${ }^{26}$ Descoñécese exactamente a situación desta pequena fortaleza, pero debía estar no couto de Cristimil. Foi derrubada polos Irmandiños, segundo se expresa no preito Tabera-Fonseca. RODRÍGUEZ GONZÁLEZ, Ángel: Las fortalezas de la Mitra compostelana y los 'Irmandiños'. Serie «Galicia Histórica». Fundación Pedro Barrié de la Maza. 1984, pp. 478-479.

${ }^{27}$ Arquivo Pazo de Don Freán. O citado documento publicado por RUBIA ALEJOS, F. e GÓMEZ BUXÁN, C.: Tocante a los Hixosdalgo.
} 


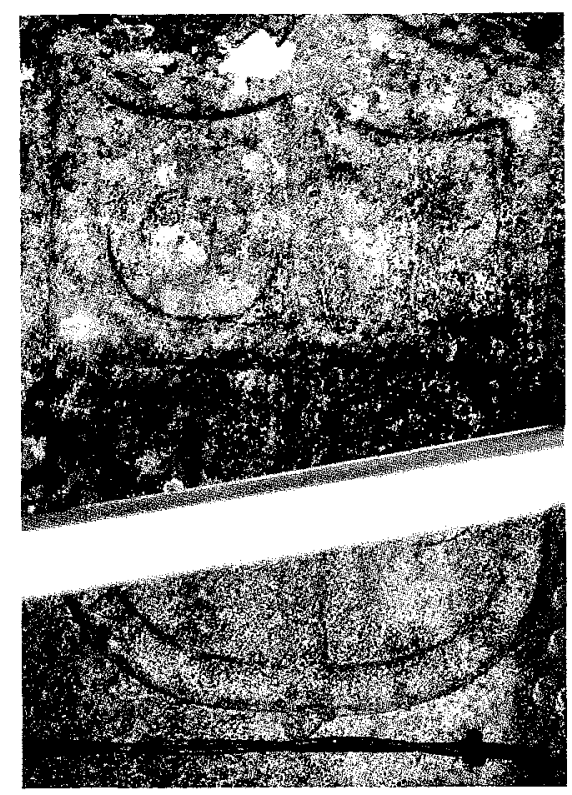

Figura 14.

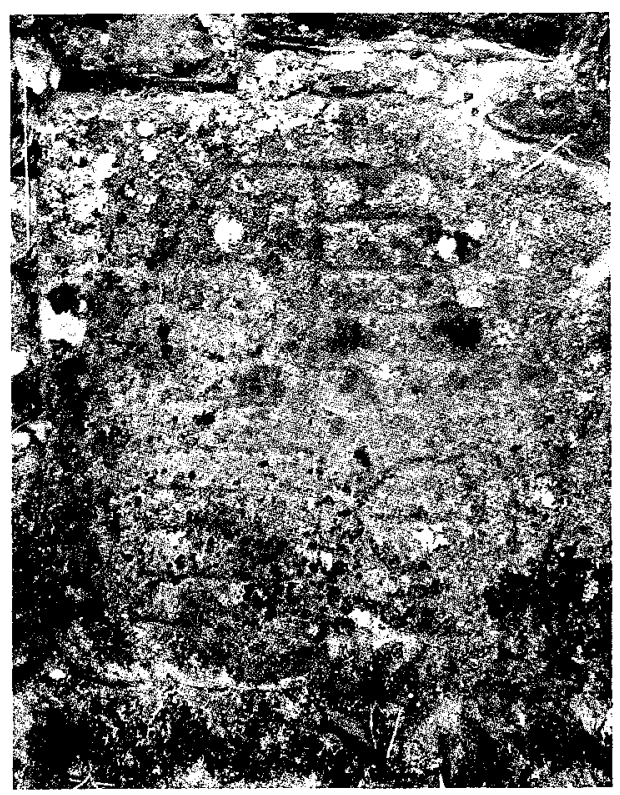

Figura 15.

portantes da zona. A súa muller, Margarida Gómez (tratándose da mesma persoa), figura citada por Manuel de Toubes sen nome, como filla de Nuño Crespo de Liñeira ${ }^{28}$.

Temos coñecemento de dous fillos da parella: Álvaro Taboada e Alonso Núñez ${ }^{29}$. Do primeiro descenden os posuidores do pazo de Liñares, en San Martiño de Prado. Do segundo quedou unha ilustre e abondosa descendencia, donos da casa de Cristimil, Remil (Santiago de Gresande), Bendoiro (San Miguel do mesmo nome), Golmar (Santa María de Noceda), Barrio (San Xoán de Anzo), Casares (San Miguel de Goiás), e tantas outras que aínda erguen o seu fidalgo ser nas terras de Deza, ou que desapareceron no transcorrer dos séculos.

Os descendentes de Álvaro Taboada mandaron ser enterrados nos primeiros tempos no citado monumento funerario de San Miguel de Goiás. Os de Alonso Núñez, en cambio, fixeron da igrexa de Santa María de Noceda o seu panteón,

${ }^{28}$ E debe tratarse da mesma, pois o 1 de marzo do 1493 o mosteiro de San Lourenzo de Carboeiro aforou a Pedro de Lineira, sobriño de Gómez Taboada, un lugar en San Xoán de Visantoña. LUCAS ÁlVAREZ, M.: El archivo del monasterio de San Martiño de Fóra o Pinario de Santiago de Compostela. Tomo II. Ediciós do Castro, Sada - A Coruña, 1999, p. 950.

${ }^{29}$ Este segundo testemuño do repetido Manuel de Toubes. 
sendo a primeira persoa alí soterrada da que teñamos constancia a muller de Alonso, Clara Rodríguez.

\subsection{Descendentes de Álvaro Taboada. Liña do pazo de Liñares}

Álvaro Taboada, fillo de Gómez Taboada «Ceita Magadeus» foi persoeiro importante nas terras de Deza e Trasdeza, das que foi xuíz pola igrexa de Santiago nas primeiras décadas do século XVI. Do seu matrimonio con Mayor Gondina tivo por herdeiro a Gómez Taboada que, como xa dixemos, habitara en San Miguel de Goiás e con posterioridade levou Liñares por arrendos, foros e vendas que lle fixeron os lexítimos donos.

O pazo de Liñares, na parroquia lalinense de San Martiño de Prado, foi edificado empregando os sillares do derruído castelo de Vilaboa ${ }^{30}$.

En principio o casar de Liñares, onde se atopaba a torre primitiva, orixe da edificación actual, era propiedade do crego Alonso Taboada, que tamén posuía o casal de Moldes, na mesma parroquia de Prado. A relación deste cos citados anteriormente non se expresa na documentación, pero queda fora de toda dúbida, pois é nomeado como albacea ou titor dos fillos menores nos testamentos de Álvaro Taboada (xa citado) e de Gómez Taboada de Brenzos. Tivo dous herdeiros este relixioso, Rui Fraiz e Gregorio Vázquez Taboada e os casares de Liñares e Moldes foron pasando por distintas mans ó longo deste século XVI, ata quedar de xeito definitivo en poder da familia que se perpetuou ata o século XX.

Gómez Taboada, como o seu pai Álvaro, exerceu de xuíz, neste caso dos coutos de Carboeiro, e segundo se di, foi destacado participante na guerra (ou escaramuza) de Chapa ${ }^{31}$. Casou dúas veces, a primeira con Leonor de Ulloa, do pazo de Pedroso, e a segunda con Ana Mosquera, da que naceu o sucesor en Liñares, Vasco Taboada Mosquera.

A comezos do século XVIII, o enlace entre don Alonso Taboada Mosquera, descendente do anterior, e dona María Andrea Taboada supuxo a unión de dous grandes patrimonios fidalgos de Deza: o pazo de Liñares e a casa de Brenzos, e tamén a unión de dúas liñas importantes dos Taboada de Deza ${ }^{32}$.

\footnotetext{
${ }^{30}$ Foi destruído durante o movemento Irmandiño e as súas pedras empregadas na edificación da antiga torre de Liñares, segundo datos existentes no arquivo do pazo de Don Freán e facilitados polo noso amigo e investigador don Francisco Rubia Alejos.

${ }^{3}$ GONZÁLEZ ALÉN, D. e VÁZQUEZ CRESPO, A.: A comarca do Deza. Deputación Provincial de Pontevedra, 1997, $2^{\text {a }}$ ed., p. 469.

${ }^{32}$ GÓMEZ BUXÁN, C.: «Xenealoxías dezanas. A desaparecida casa de Brenzos». Anuario de Estudios e Investigación Descubrindo, $\mathrm{n}^{\circ}$ 4. Lalín, 2002, pp. 11-27.
} 
A fundación do vínculo e morgado de Liñares data do 7 de xuño do $1625^{33}$. No documento, outorgado ante o escribán Gonzalo Rodríguez de Torres, o dono do pazo de Liñares, Vasco Taboada Mosquera «para serviçio de Dios nuestro senor como de nuestros reis y senores nacturales y por onrra y defensa de mi linaje y cassa por los Exenplos de los savios antigos de todas naçiones para instituir los semejantes mayorazgos e ynstituçiones», e para que casase o seu fillo e da súa segunda muller, Beatriz Salgada, Alonso Taboada Mosquera, con Catalina Taboada (filla do seu parente ${ }^{34}$ Gonzalo Taboada y Ulloa, do pazo de Golmar, en Noceda), institúe o morgado de Liñares, con informacións de grande importancia e interese para o estudio da heráldica desta familia.

No vínculo inclúese «las mis casas y paços de linares con todas sus casas corrales, torres, salas alto y baxo caballeriças y con todas sus tierras y eredades prados pastos nabales debesas soutos pumares eredades palomar y cercas de la dicha cassa (...) con mas la mi Jurisdiccion y coto de San Jurjo de Crestemill fortaleza de billaboa donde vengo y desciendo con toda su Jurisdicion cebill y creminal mero misto ynperio lugares rentas serviçios que tengo dentro de la dicha Jurisdiccion y renta viene y esta reconoscida por bienes de mayorazgo, de mi padre y abuelos que no a sido partido ni debedido...».

Como condición expresa pon «que el varon o enbra que suscediere en este mayorazgo y marido que con ella casara tome el apellido prinçipal de los tavoadas y pongan las armas de mi linaje questan en mis casas en los escudos de armas que son ruedas calderas y tres tablas y treze roeles y tres barras questan en mis hescudos». Temos aquí, pois, o resumo das armerías empregadas desde antigo por esta póla dos Taboada que habitou no pazo de Liñares e que figuran representadas nas pedras armeiras que aínda se conservan.

Estas, situadas no antepeito da galería da fachada posterior do pazo, datan do século XVI e sufriron un gran desgaste, quizais derivado dos traslados que sufriron ata chegar ó emprazamento actual (Figura 16).

O escudo da destra é partido e medio cortado, co segundo cuartel liso, aparentando estar inacabado. Trae as seguintes armas:

$1^{\circ}$. Tres flores de lis mal ordenadas.

$2^{\circ}$. Dúas rodas de carro superadas cada unha delas de dúas táboas.

$3^{\circ}$. En branco.

\footnotetext{
${ }^{33}$ Arquivo Gómez Buxán (AGB), protocolos, Gonzalo Rodríguez, 1625.

${ }^{34}$ «nuestros deudos porque todos benimos y desçendemos de un truenco, y linaje y tenemos mistos algunos bienes que an quedado de nuestros abolengos».
} 
Como vemos, no segundo cuartel dispóñense as mesmas armas que no sepulcro de San Miguel de Goiás (táboas e rodas de carro) e as tres lises do primeiro cuartel non coñecemos a que liñaxe se poden atribuír.

Ó escudo da sinistra fáltalle parte da zona superior. É cuartelado en cruz coas seguintes armas:

$1^{\circ}$. Tres flores de lis mal ordenadas.

$2^{\circ}$. Tres caldeiras mal ordenadas.

$3^{\circ}$. Dúas rodas de carro, superada a da destra de tres varelas e a da sinistra de tres táboas.

$4^{\circ}$. Roeis en dous pales. Debido ó desgaste, aprécianse dez (o máis probable é que fosen trece).

Desta labra consérvase un debuxo atribuído a Enrique Campo no Museo de Pontevedra, no que se aprecian as armas que se describiron con anterioridade (Figura 17), con algunha variación que non afecta ó esencial da armería, como é a forma do escudo e o tamaño dos mobles que no seu campo se dispoñen.

A correlación, unha vez coñecida fundación do vínculo e morgado de Liñares é clara: ós Taboada corresponden os cuarteis segundo, terceiro e cuarto. As táboas que xa figuraban nas labras anteriores, tanto na de Goiás como na outra de Liñares xa citada, transfórmanse en táboas e varelas (as varas ou barras citadas na fundación do morgado), quizais por asimilación cos Varela en unión coas lises do primeiro cuartel, unha vez perdida a memoria da súa primitiva significación.

Dentro da igrexa parroquial de Prado consérvase un interesante exemplar que representa unha evolución na representación das armas dos Taboada (Figura 18). Esta lápida corresponde, segundo Enrique Campo ${ }^{35}$ a Antonio Taboada Mosquera, do que non se nos ofrecen máis datos. Podería ser o que era chamado a suceder ó seu pai Vasco Taboada Mosquera en Liñares, xa que foi mellorado por el nos seus bens, pero faleceu sen sucesión a primeiros do século XVII ${ }^{36}$. Debido ás obras levadas a cabo na igrexa a finais do século XIX, parte da inscrición quedou destruída, léndose $D A: M A N D O \ldots$... ESTA YGLA ... OS ANEGAS DE PA ... por riba da labra

\footnotetext{
${ }^{35}$ No pé do debuxo do escudo da fachada posterior de Liñares afirma que hai outro na igrexa parroquial coas mesmas armas, correspondente a este Antonio Taboada Mosquera.

${ }^{36}$ Era fillo do citado Vasco Taboada Mosquera e da súa primeira muller Aldonza Varela e o vínculo debeu ser outorgado para o seu matrimonio con María Núñez, filla de Gregorio Núñez de Taboada, do pazo de Bendoiro, e, por tanto, parente do noivo.
} 


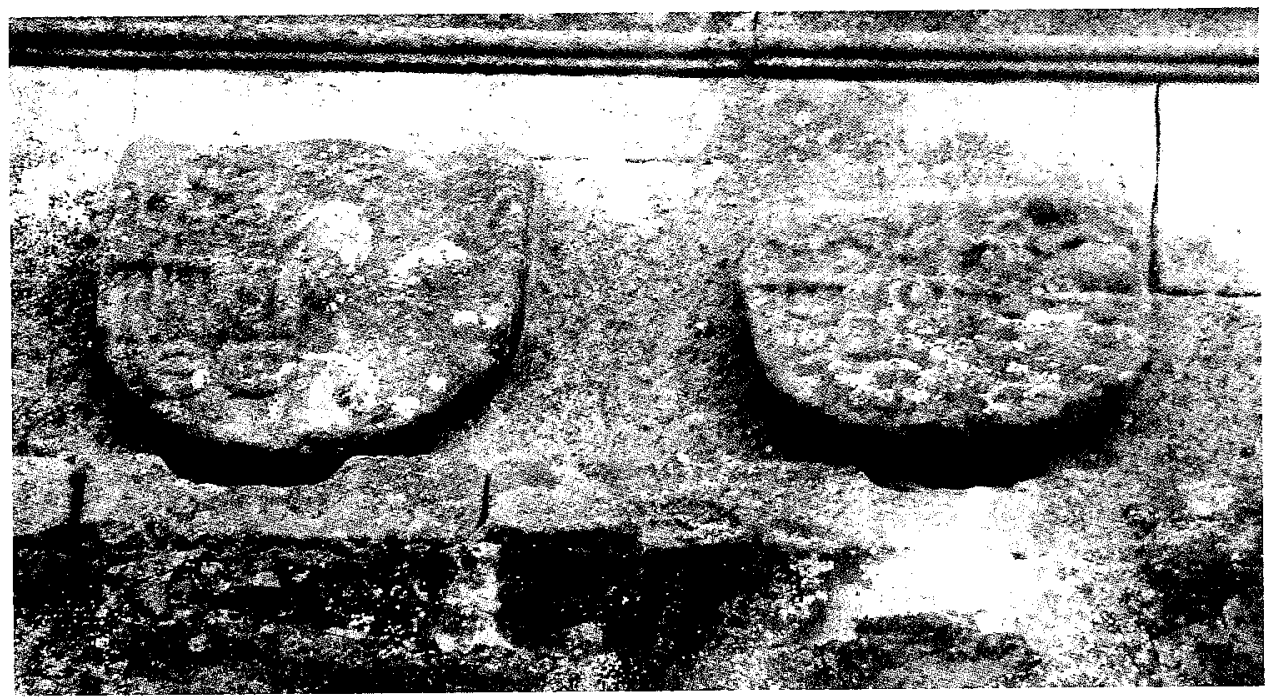

Figura 16.

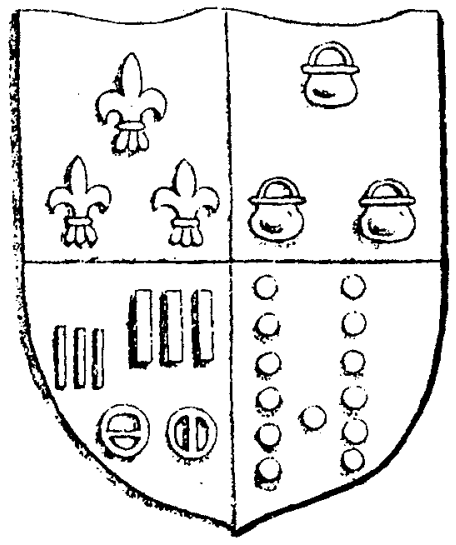

Figura 17.-

(Museo de Pontevedra).

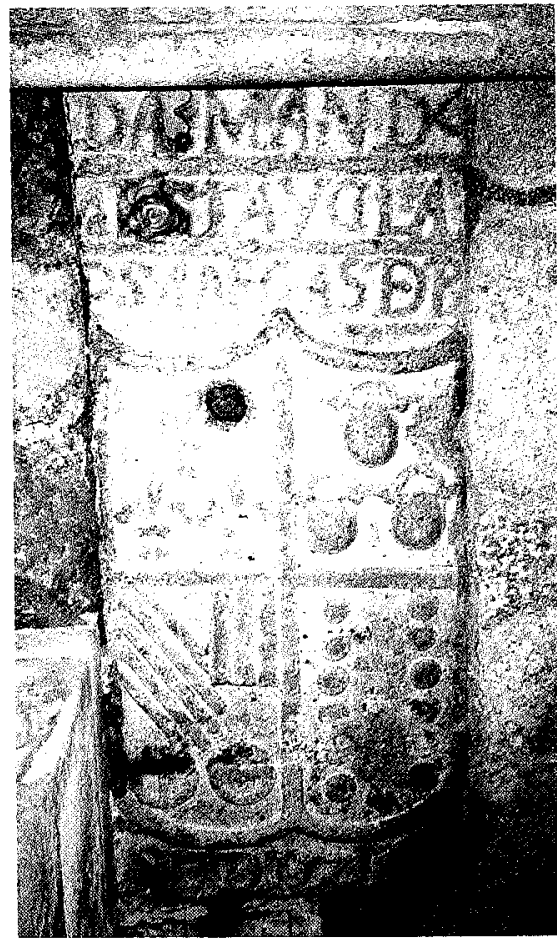

Figura 18. 
heráldica, e por debaixo tamén se conservan restos ilexibles da longa lenda que tería a lápida no pasado.

Sobre unha lápida, é un escudo con escotaduras na parte superior e dobre curvatura na inferior. Cuartelado en cruz, coas seguintes armas:

$1^{\circ}$. Tres flores de lis mal ordenadas.

$2^{\circ}$. Tres caldeiras mal ordenadas.

$3^{\circ}$. Dúas rodas de carro superada a da destra de cinco varas e a da sinistra de tres táboas.

$4^{0}$. Trece roeis en tres pales $(6-1-6)$.

O máis característico é a aparición das cinco varas (xa en banda) alusivas ós Varela, en troques das táboas e varas en pal que figuraban nas labras anteriores.

Finalmente, na fachada principal do pazo de Liñares, emprazado nunha peineta barroca rematada por pináculos, existe una labra xa máis moderna (Figura 19), en forma de óvalo sobre cartela, cuartelado en cruz. Tamén dela se conserva un debuxo de Enrique Campo no Museo de Pontevedra (Figura 20):

$1^{\circ}$. Tres táboas e bordura de oito caldeiras (TABOADA).

$2^{\circ}$. Cinco cabezas de lobo arrincadas (MOSQUERA).

$3^{\circ}$. Un castelo sobre ondas nas que nadan dúas troitas, deitado de dúas cunchas de vieira (CHURRUCHAOS).

$4^{\circ}$. Trece roeis en tres pales (5-4-4) polos LÓPEZ DE LEMOS.

Ó timbre, coroa.

Só resta citar desta liña unha representación en madeira que, segundo debuxo do repetido Enrique Campo, existía nun «armario antiguo» en Liñares (Figura 21). Nela vemos no primeiro cuartel as tres flores de lis, no segundo tres cabezas de lobo dos Mosquera, no terceiro oito roeis e tres táboas, e no cuarto dúas rodas de carro superadas de dúas caldeiras.

\subsection{Descendentes de Alonso Núñez. Liña de Bendoiro}

O outro dos fillos de Gómez Taboada «Ceita Magadeus» foi Alonso Núñez do que non temos máis constancia documental que a citada carta de Manuel de Toubes, na que non se indica a súa residencia. Casara con Clara Rodríguez de Deza (filla de García Rodríguez de Deza), enterrada na igrexa de Santa María de Noceda, tal e como se expresa nos testamentos dos seus fillos. 


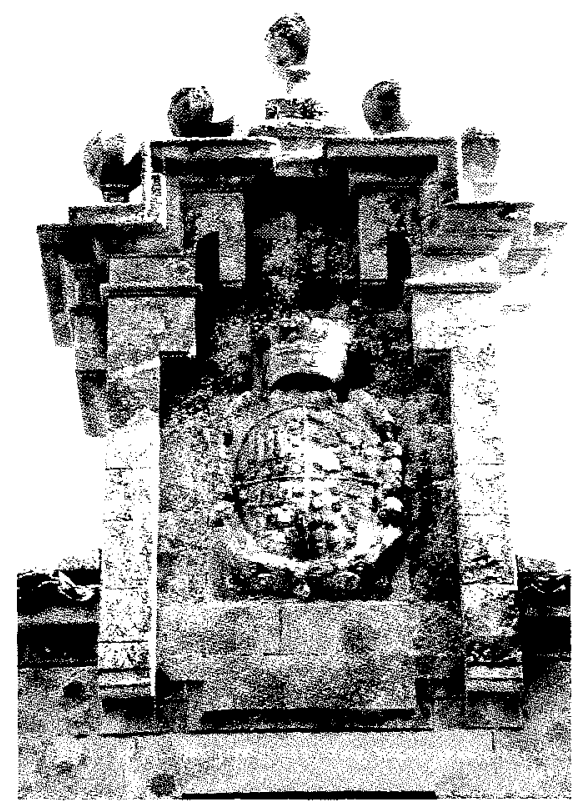

Figura 19.

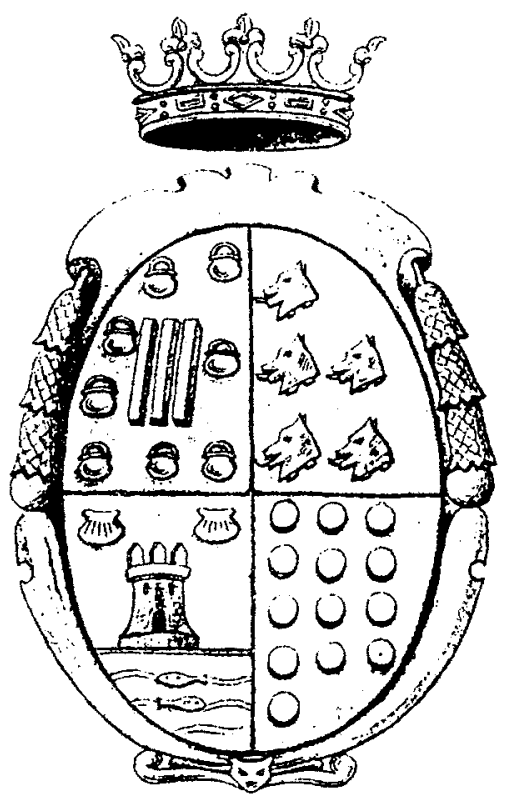

Figura 20.- (Museo de Pontevedra).

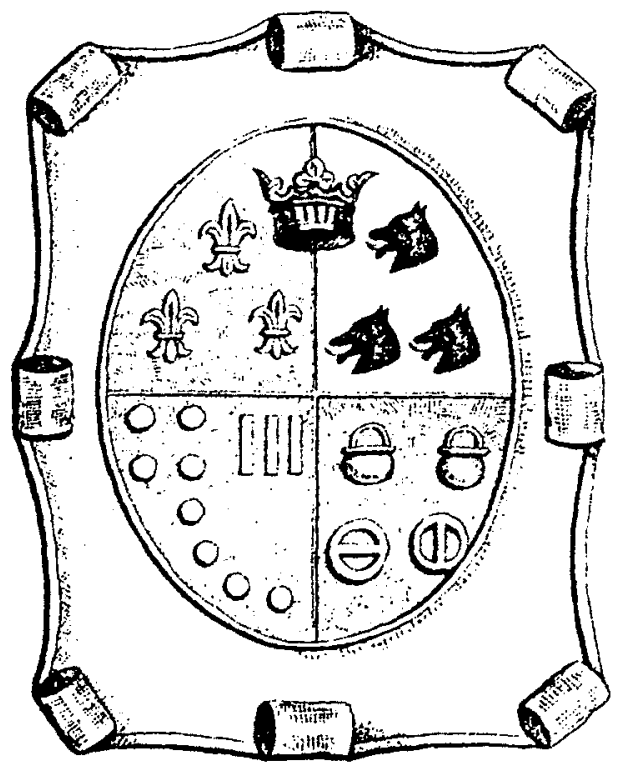

Figura 21.- (Museo de Pontevedra). 
As casas fidalgas que descenden deste Alonso Núñez adoptaron por armas as que con anterioridade se sinalaron como dos Taboada, engadindo as dos Churruchaos pola súa nai.

Alonso Núñez e Clara Rodríguez foron pais de varios fillos, entre os que destacaremos a outro Alonso Núñez (casa de Cristimil), a Gómez Taboada (casa de Brenzos-Losón) e a Gregorio Núñez (casa de Ramil-Gresande).

Do primeiro deles, Alonso Núñez, e da súa liña non se conservan testemuñas heráldicas. Era escudeiro e tiña casa en Cristimil, na que residía. O 26 de outubro do $1524^{37}$ outorga o seu testamento «preso en la carçel y fortaleza» da vila de Pontedeume, xa que ía ser degolado ó día seguinte. Nel ordena ser sepultado na igrexa de San Francisco de Pontedeume e «despues de seren gastadas mys carnes que mys herederos fagan sacar mys huesos y los fagan leevar a la yglesia de santa maria de nozeda donde jaz my madre».

Casou con Leonor Vázquez Pereira, de nobre familia de terras ourensás, e dela tivo por fillos a: Vasco Fernández, Pedro Pereyra, Manuel de Toubes, Catalina Barata, Beatriz Afonso e Clara Rodríguez, así como outro do que estaba embarazada no intre do testamento a súa muller, ó que ordena chamen (se é varon) Afonso Núñez.

No fillo Manuel de Toubes, máis adiante alcumado «el Viejo», seguiu a sucesión do couto e casa de Cristimil. Casou en dúas ocasións, a primeira con Teresa Sánchez, do pazo de Soutolongo, e a segunda con María Varela. Dos dous matrimonios tivo descendencia, seguindo a sucesión un dos fillos do segundo enlace, chamado Manuel de Toubes, el Mozo.

Este, do seu matrimonio con Mencia López non tivo descendencia, polo que pasou a sucesión dos seus bens, entre os que se atopaba o couto de Cristimil, á súa irmá Isabel López Varela, muller de Gómez Oxea de Albán, dono do pazo de Donfreán, en Santiago de Catasós, co que remata a sucesión directa agnaticia dos posuidores desta parte do couto de Cristimil.

\subsubsection{Descendentes de Gómez Taboada. Liña de Brenzos.}

A casa de Brenzos, en Santa Baia de Losón, deriva directamente das de Cristimil, Ramil, Cercio e Pedroso.

Gómez Taboada, escudeiro, fillo de Alonso Núñez e de Clara Rodríguez de Deza, dos que xa temos falado con anterioridade, casou con Urraca Rodríguez Monteagudo, filla dos señores de Cercio e Pedroso, Vasco Barreiro e Leonor

${ }^{37}$ Arquivo Pazo de Don Freán. Extracto do documento publicado por RUBIA ALEJOS, F. e GÓMEZ BUXÁN, C.: Tocante a los Hixosdalgo.

Cuadernos de Estudios Gallegos, Tomo LII, Fascículo 118, Santiago 2005. (Págs. 389 - 426) 
Vázquez. O matrimonio levou o lugar de Brenzos, en Santa Baia de Losón, sendo raíz de importantes casas nobres. Gómez outorgou testamento no $1512^{38}$, ordenando ser sepultado na igrexa de Santa María de Noceda. Do matrimonio naceron: Alonso Saco de Taboada, do que falaremos máis adiante, que pasou a casar á casa de Viñoa (Santa María de Soutolongo), Gonzalo Taboada, que segue en Brenzos, Margarita Taboada, Alonso Núñez, crego, Gómez Taboada e Leonor Taboada.

Segue a liña Gonzalo Taboada Monteagudo, escudeiro, señor da casa de Brenzos por herdanza dos seus pais. Outorgou o seu testamento ante o escribán Cristóbal Gundín o 1 de outubro do $1572^{39}$, e manda que o enterren, como o seu pai, dentro da igrexa de Santa María de Noceda, falecendo pouco despois. Casou coa súa parente Inés Pérez Mosquera, e deles naceron : Vasco Taboada, que segue, Gómez Taboada, el Mozo, Catalina Pérez, Urraca Rodríguez e María Taboada.

Vasco Taboada do Carrio foi xuíz de Trasdeza no 1586 e de Carboeiro figura no 1590 e 1606. Fundou o vínculo de Brenzos ante o escribán Gonzalo Rodríguez, e o seu testamento pasou ante Gregorio García o 6 de xaneiro do 1637. Morreu no 1643 e foi sepultado dentro da igrexa de Losón, nun monumento con labra heráldica no frontis e estatua orante ${ }^{40}$. Casara con María Rodríguez Rebellón e deles descenden os sucesivos señores de Brenzos e de Liñares.

No que atinxe á heráldica desta liña, posiblemente a labra heráldica que hoxe se conserva no interior de Liñares proceda de Brenzos, tal e como expresa Enrique Campo cando o debuxa a comezos do século $\mathrm{XX}^{41}$ (Figura 22). Certo que a súa fonte foi a tradición oral, pois nesa época aínda habitaban o pazo de Liñares os Taboada, descendentes seculares dos escudeiros de Brenzos.

No interior atopamos, pois, unha pedra armeira en forma de cartela armoriada co contorno habitual noutras labras da comarca de Deza, a pel animal apergamiñada,

${ }^{38}$ AHUS, protocolos, Gómez de Barral, 1512.

${ }^{39}$ AHUS, protocolos, Cristóbal Gundín, 1572.

${ }^{40}$ Algúns autores afirman que esta sepultura corresponde a Vasco Taboada Mosquera, dono de Liñares, baseándose no padroado que este pazo exercera sobre a parroquia de Santa Baia de Losón, pero sen reparar que este feito arrinca da unión entre Liñares e Brenzos (casa á que lle correspondía a presentación deste beneficio) a comezos do século XVIII. Por outra banda, no testamento de dona Catalina Taboada, muller de don Alonso Taboada Mosquera, dono de Liñares, outorgado o 3 de decembro do 1643, queda mandado «que si nuestro señor fuere servido llebarme desta enfermedad, mis carnes pecadoras sean sepultadas dentro dela iglesia de san martino de prado en la sepultura donde hesta Basco tavoada mi suegro». Arquivo Histórico Provincial de Pontevedra, protocolos, Gregorio Rodríguez de Castro, 1658.

${ }^{41}$ A visita data do 1909, realizada por Enrique Mayer e Enrique Campo. «El recorrido arqueológico de Mayer y E. Campo en 1909», Museo de Pontevedra, Tomo III, 1944-45. Ed. facsimilar da Deputación de Pontevedra, 2000, pp. 157-171. 


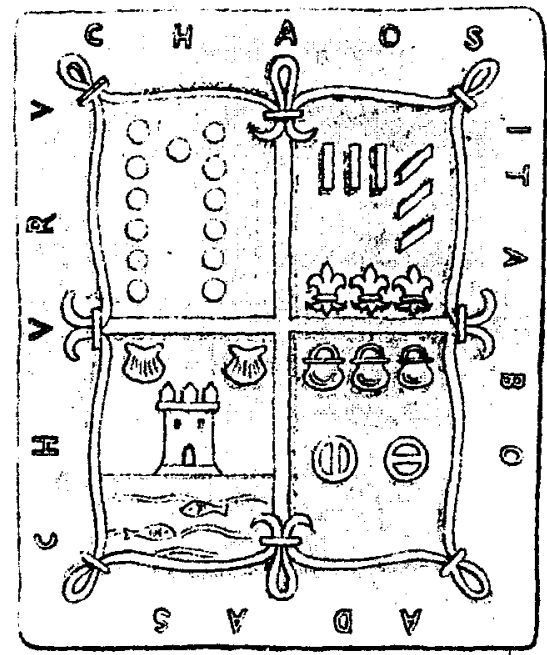

Figura 22.

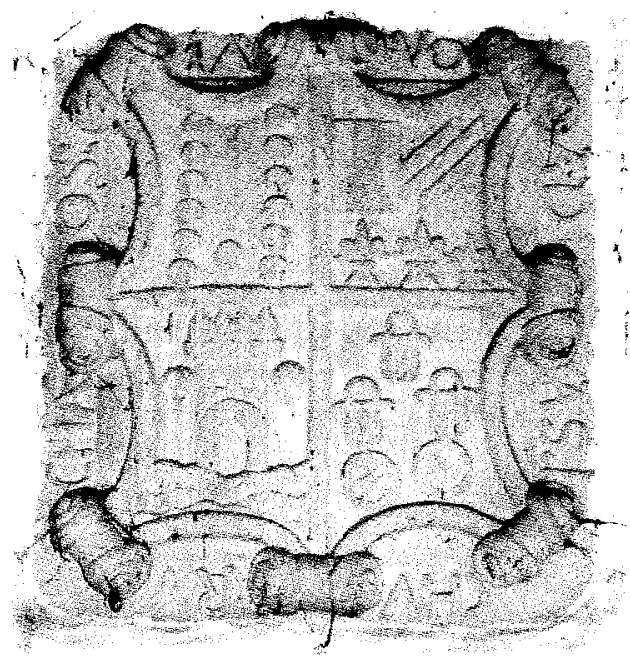

Figura 23.

característica na zona nos séculos XVI e XVII (Figura 23). A súa factura é moi coidada e demostrativa de que a realizou un bo profesional da cantería. O campo é cuartelado en cruz, coas armas típicas desta liña, é dicir, as dos Taboada e os Churruchaos:

$1^{\circ}$. Trece roeis en tres pales $(6-1-6)$.

$2^{\circ}$. Tres flores de lis en faixa superadas no cantón destro do xefe de tres táboas e á sinistra de tres varas.

$3^{\circ}$. Unha torre almenada sobre ondas, con dúas troitas nadando entre as augas, deitada de dúas cunchas de vieira (CHURRUCHAOS).

$4^{0}$. Dúas rodas de carreta ${ }^{42}$ superadas de tres caldeiras mal ordenadas.

Arredor da cartela, o epígrafe: TAVOADAS I CHVRVCHANOS.

Similar ou practicamente igual a esta pedra armeira existe outra na Casa Grande de Val (Santo André de Val do Carrio), emprazada nunha esquina da torre. A razón da súa colocación neste pazo e a súa orixe non se coñecen, pero está relacio-

\footnotetext{
${ }^{42}$ Aínda que se refire ós CAMBA, non se trata das típicas rodas do carro galego, senón rodas de carreta cos radios ben marcados, sinal dunha influencia máis culta.
} 


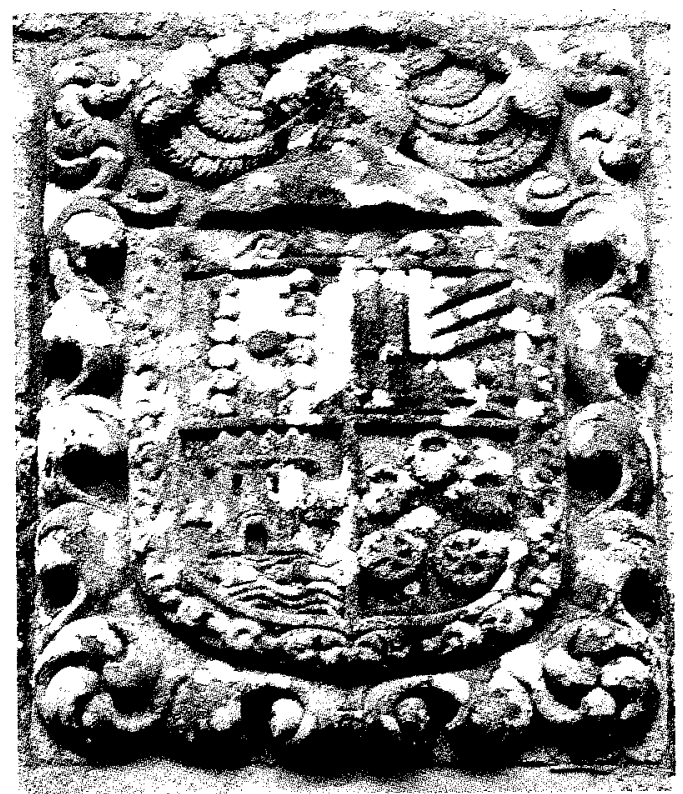

Figura 24.

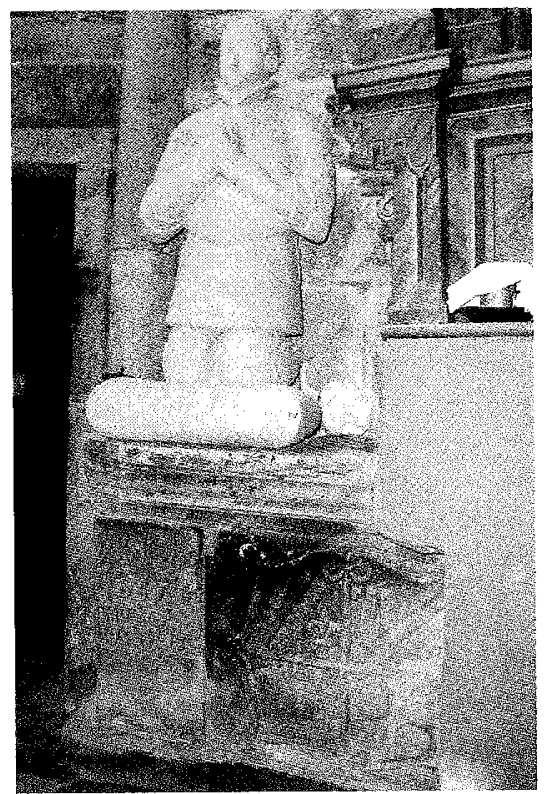

Figura 25.

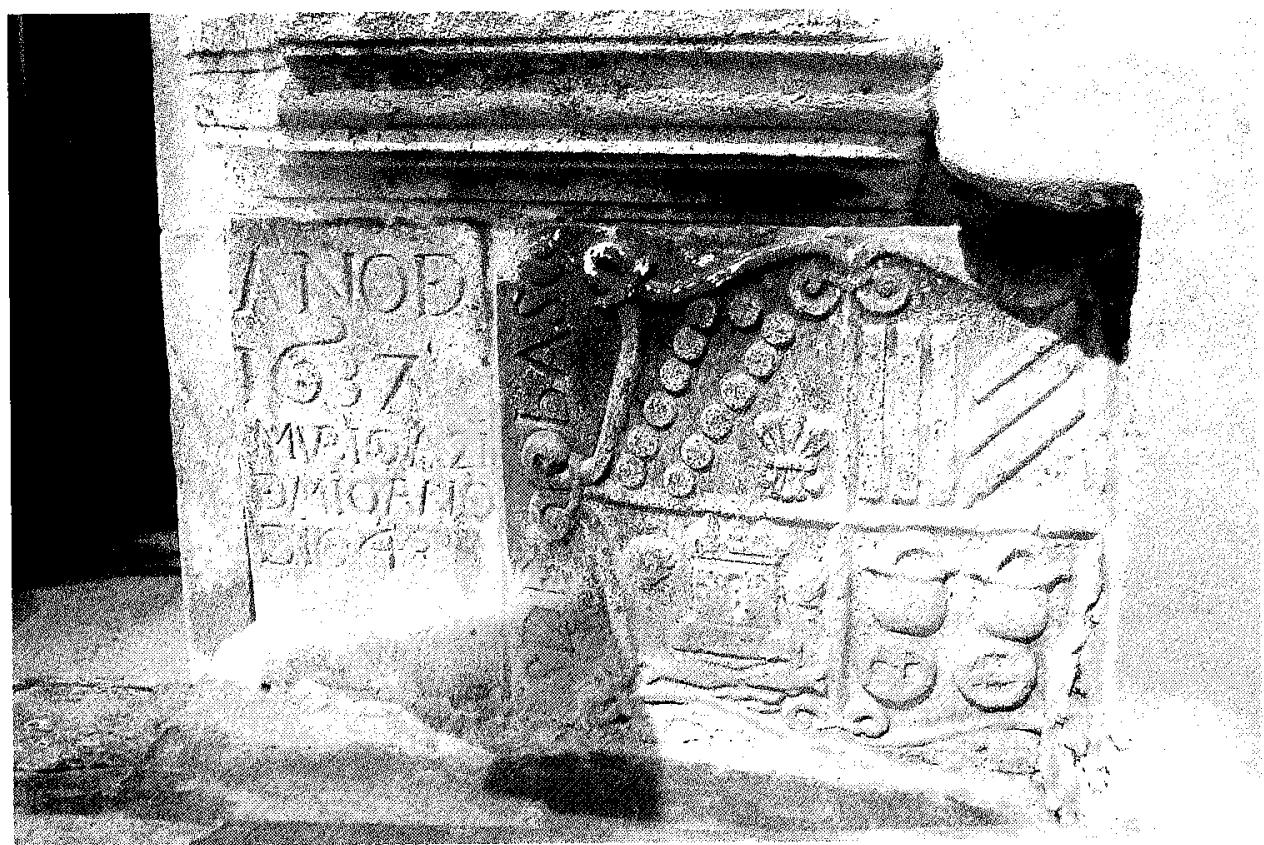

Figura 26. 
nada coa anterior ${ }^{43}$, con mínimas diferencias (forma, ornamentación e timbre e, por tanto, non esenciais) e iguais nas armas (Figura 24).

Outra representación heráldica pertencente a esta liña é a que xa citamos como existente no frontis do sepulcro de Vasco Taboada no interior da igrexa de Losón (Figura 25). É unha labra de contorno cuadrangular cunha decoración con volutas estilizadas (Figura 26). Cuartelada en cruz trae as seguintes armas:

$1^{\circ}$. Trece roeis sinistrados dunha lis.

$2^{\circ}$. Tres táboas sinistradas de tres varas.

$3^{\circ}$. Unha torre almenada sobre ondas nas que nadan dúas troitas, deitada de dúas cunchas de vieira.

$4^{\circ}$. Dúas rodas de carro en faixa, sumada cada unha delas dunha caldeira.

Como vemos, representa unha simplificación da labra interior de Liñares (as tres lises convértense en unha). A súa factura é correcta, mentres que a da estatua orante é moi basta e inexpresiva, unido ó feito da limpeza agresiva á que foi sometida que erosionou grande parte dos relevos e da pátina que a cubría.

No lateral da pedra armeira unha inscrición: ANO DE / 1637/ MVRIO A 21 / DE MAIO ANO / DE 1643. A primeira data é coetánea do monumento funerario e coincide coa do testamento de Vasco Taboada do Carrio.

Non podemos deixar de citar outro fillo de Gómez Taboada e de Urraca Rodríguez Monteagudo, chamado Alonso Saco de Taboada. Casara con Isabel Sánchez de Ulloa, pasando a residir no lugar de Viñoa da parroquia de Santa María de Soutolongo, onde aínda se conserva unha edificación fidalga con dous interesantes escudos.

O da dereita segundo o observador (Figura 27) está labrado nun bloque curioso, tanto polo tipo de roca e cor da mesma como por ser unha peza empregada doutra construcción anterior. De coidada factura, con escotaduras na parte superior, pódese datar posiblemente na segunda metade do século XVI. Cuartelado en cruz, trae as seguintes armas:

$1^{\circ}$. Unha flor de lis co tallo prolongado.

$2^{\circ}$. Catro faixas (táboas?).

${ }_{43}^{43}$ Pódese deber ó matrimonio de don Antonio Varela Taboada, dono da casa, con dona Magdalena Gil Taboada, procedente do pazo de Bergazos (Santa Baia de Donsión), primeira muller que fora de don Andrés Taboada, dono do pazo de Brenzos, neto do citado Vasco Taboada do Carrio.

Cuadernos de Estudios Gallegos, Tomo LII, Fascículo 118, Santiago 2005. (Págs. 389 - 426) 


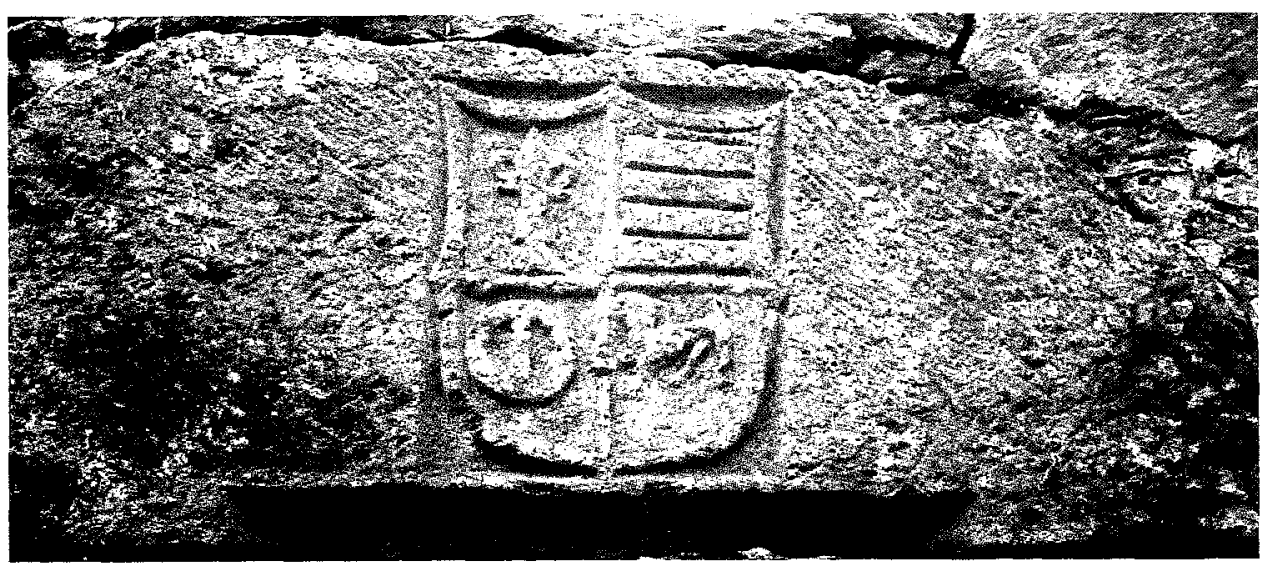

Figura 27.

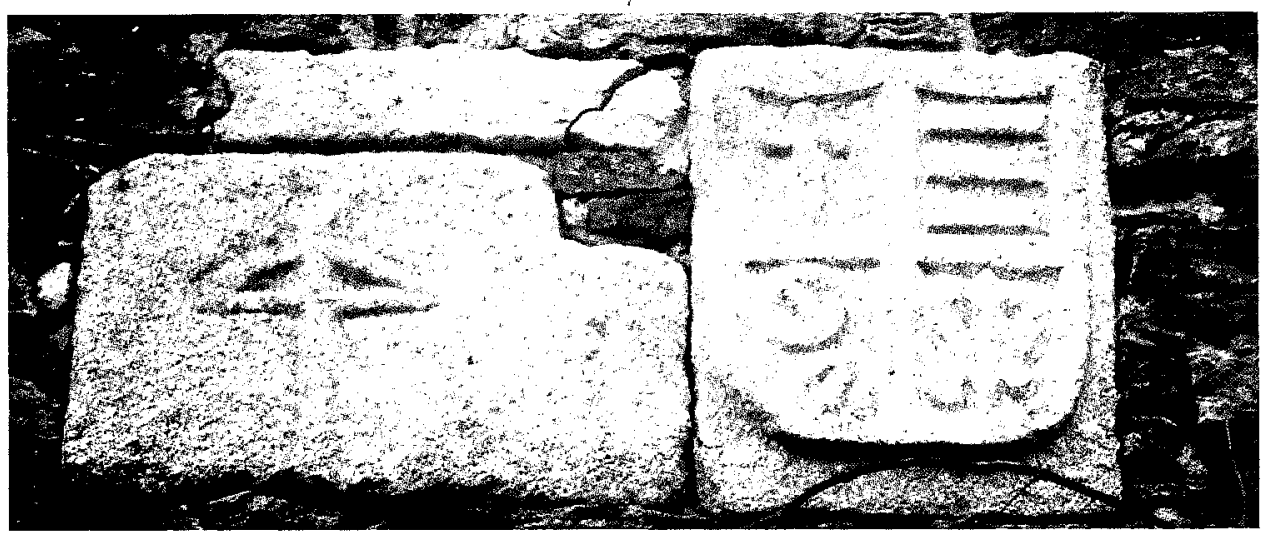

Figura 28.

$3^{\circ}$. Unha roda de carro.

$4^{\circ}$. Un cuadrúpedo pasante, posiblemente un león.

$\mathrm{O}$ da esquerda (Figura 28) é tamén de feitura antiga, aínda que de peor calidade que o anterior. Cuartelado en cruz, trae as seguintes armas:

$1^{\circ}$. Nun debuxo de mediados do século $\mathrm{XX}$ deste escudo figura o moble como unha espada.

$2^{\circ}$. Tres faixas.

$3^{\circ}$. Dúas rodas de carro.

$4^{\circ}$. Unha flor de lis. 
Á beira deste escudo disponse unha figura que representa unha ballesta. A composición é o resultado de asentar en séculos pasados xunto á pedra armeira un sillar doutra procedencia.

A identificación das armas das dúas labras non nos é posible, pero a aparición da roda de carro e das faixas ou táboas leva a supoñer que son posteriores ó entronque coa casa de Brenzos, a mediados do século XVI, facendo referencia ós Taboada. Quizais as flores de lis fagan referencia ós Froiz, dos que procedía a citada Isabel Sánchez de Ulloa ${ }^{44}$.

\subsubsection{Descendencia de Gregorio Núñez. Liña de Bendoiro}

As armerías que evolucionan seguindo a descendencia do pazo de Bendoiro son as máis numerosas de tódalas que temos visto na comarca de Deza.

Descenden os de Bendoiro da casa de Cristimil e da de Ramil. Como xa dixemos anteriormente, dun dos fillos de Gómez Taboada «Ceita Magadeus», chamado Alonso Núñez, naceu, entre outros, Gregorio Núñez, dono dos lugares de Ramil, Cristimil e San Xurxo. Del naceron varios fillos, entre eles: Alonso Núñez de Taboada, Gregorio Gutiérrez, que segue vivindo en Gresande, Violante Taboada e Catalina Taboada.

Alonso Núñez de Taboada constitúese no primeiro posuidor de Bendoiro do que temos constancia documental. Outorgou testamento o 12 de abril do 1597 ante o escribán Francisco López ${ }^{45}$, mandando nel «que mys carnes pecadoras sean sepultadas dentro de la yglesia de san miguel de bendoyro (...) e me entierren y me ponga una sepultura buena con las armas de los tauoadas y churruchaos de donde bengo y desciendo...».

A súa muller foi Margarita López, descendente da liñaxe dos Infanzóns de Soutolongo ${ }^{46}$, que finou no 1609.

Tivo o matrimonio seis fillos: Alonso Saco de Taboada, Gregorio Núñez de Taboada, Gonzalo Taboada y Ulloa, Inés Vázquez de Taboada, Clara Rodríguez de Torres e Álvaro López de Taboada, crego.

${ }^{44}$ As armas dos Froiz, segundo nos di Manuel de Toubes, eran «flor de lisas».

${ }^{45}$ AGB, protocolos.

${ }^{46}$ Era filla de Pedro López de Sotolongo e da súa muller Inés Vázquez Varela, donos do pazo de Soutolongo, antiga residencia fidalga da que hai coñecemento desde o século XV. Das súas tres pedras armeiras, dúas son similares, datadas a comezos do século XVII (unha delas, segundo a inscrición, do 1616), coas mesmas armas nun partido: no primeiro cuartel unha torre almenada superada de tres flores de lis, e no segundo cuartel unha árbore arrincada resaltada dun león pasante. 


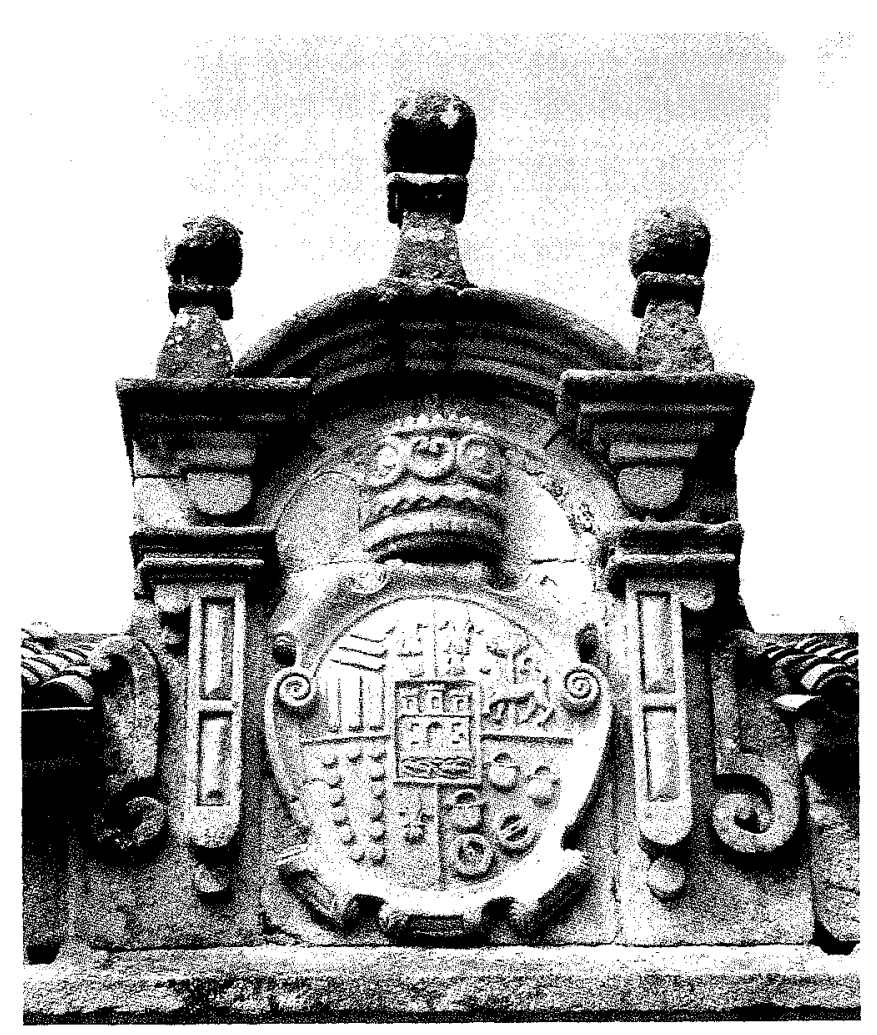

Figura 29.

\section{Liña de Alonso Saco de Taboada}

Alonso Saco de Taboada partiu o lugar de Bendoiro de Abaixo cos seus irmáns Gregorio e Gonzalo, segundo disposición testamentaria do seu pai. Levou tamén a casa de Bendoiro por razón de mellora de tercio de quinto que o mesmo lle fixo. Dos descendentes do seu matrimonio con Mencia García, procedente do couto de Porreiros, en Gresande, descenden os propietarios do pazo de Bendoiro de Abaixo ata finais do século XX.

A labra heráldica (Figura 29), testemuña da nobreza dos habitantes do pazo de Bendoiro, atópase situada sobre o portón de entrada, nunha peineta barroca que enmarca a labra propiamente dita, en forma oval sobre cartela, dispoñéndose as armas nun cuartelado en cruz con escusón:

$1^{\circ}$. Tres táboas, superadas de tres varas, estas últimas adestradas dunha cuncha de vieira superada dunha flor de lis. 
$2^{\circ}$. Árbore resaltada dun can pasante, sinistrado dunha flor de lis.

$3^{\circ}$. Trece roeis en tres pales (6-1-6), adestrados dunha flor de lis.

$4^{\circ}$. Dúas rodas de carro superadas de tres caldeiras.

ESCUSÓN. Castelo sobre ondas nas que nadan dúas troitas.

O máis característico, ademais do escusón cuadrangular, é o feito de que as flores de lis se atopen repartidas en tres cuarteis, así como as cunchas de vieira nos cuarteis primeiro e segundo en vez de ós lados do castelo dos Churruchaos (falta espacio no escusón para tódolos mobles).

Nesta labra, ademais das armas características dos Taboada, figuran no segundo cuartel as dos «Infanzóns de Soutolongo», segundo interpretación do século XVIII que toma ó pé da letra a inscrición existente nas pedras armeiras do pazo de Soutolongo. Pero hai que ter en conta que neste último aparece representada unha árbore resaltada dun leon pasante, que foi sufrindo variacións no tempo ata chegar ó can que aparece na pedra armeira de Bendoiro ${ }^{47}$.

\section{Liña de Gregorio Núñez de Taboada}

Outro dos fillos de Alonso Núñez de Bendoiro e de Margarida López, foi Gregorio Núñez de Taboada, escribán da Súa Maxestade, tal e como figura do 1583 ó 1616. Partiu o lugar de Bendoiro de Baixo, segundo dixemos, co seu irmán Alonso, titulándose señor do pazo de Bendoiro, construcción que se conserva, aínda que moi modificada, inmediata ó pazo de Bendoiro de Abaixo.

Casou con Inés Alonso, filla dos donos da casa de García Sánchez (San Cristobo da Pena), fundando a Capela «del Buen Jesús», na igrexa parroquial de Bendoiro, onde foi sepultado o matrimonio. A data de fundación é do 1616 e na visita que se levou a cabo no 1625 xa estaba construída ${ }^{48}$.

Nesta capela atopamos un sepulcro baixo arcosolio con estatua xacente do fundador, Gregorio Núñez de Taboada. Consérvase un debuxo de Enrique Campo no Museo de Pontevedra no que se aprecia a inscripción do arco e as dúas pedras armeiras do conxunto (Figura 30).

${ }^{47}$ A árbore co can pasante atribúese ós Arias noutras labras da zona, como as existentes na igrexa de Goiás. Teñen gran similitude as armas do pazo de Soutolongo coas do pazo de San Martiño das Varelas (Melide), e do que procedía Aldonza Yáñez de Boado, primeira muller de Alonso Gondín de Soutolongo, dono da casa dos Infanzóns a finais do século XVI. Unha imaxe da pedra armeira melidense en «Terra de Melide». Ed. facsimilar. Ediciós do Castro, Sada. 1978, pp. 245-248.

${ }^{48}$ RUBIA ALEJOS, F. e GÓMEZ BUXÁN, C.: «Tocante a los Hixosdalgo», pp. 53-54. 


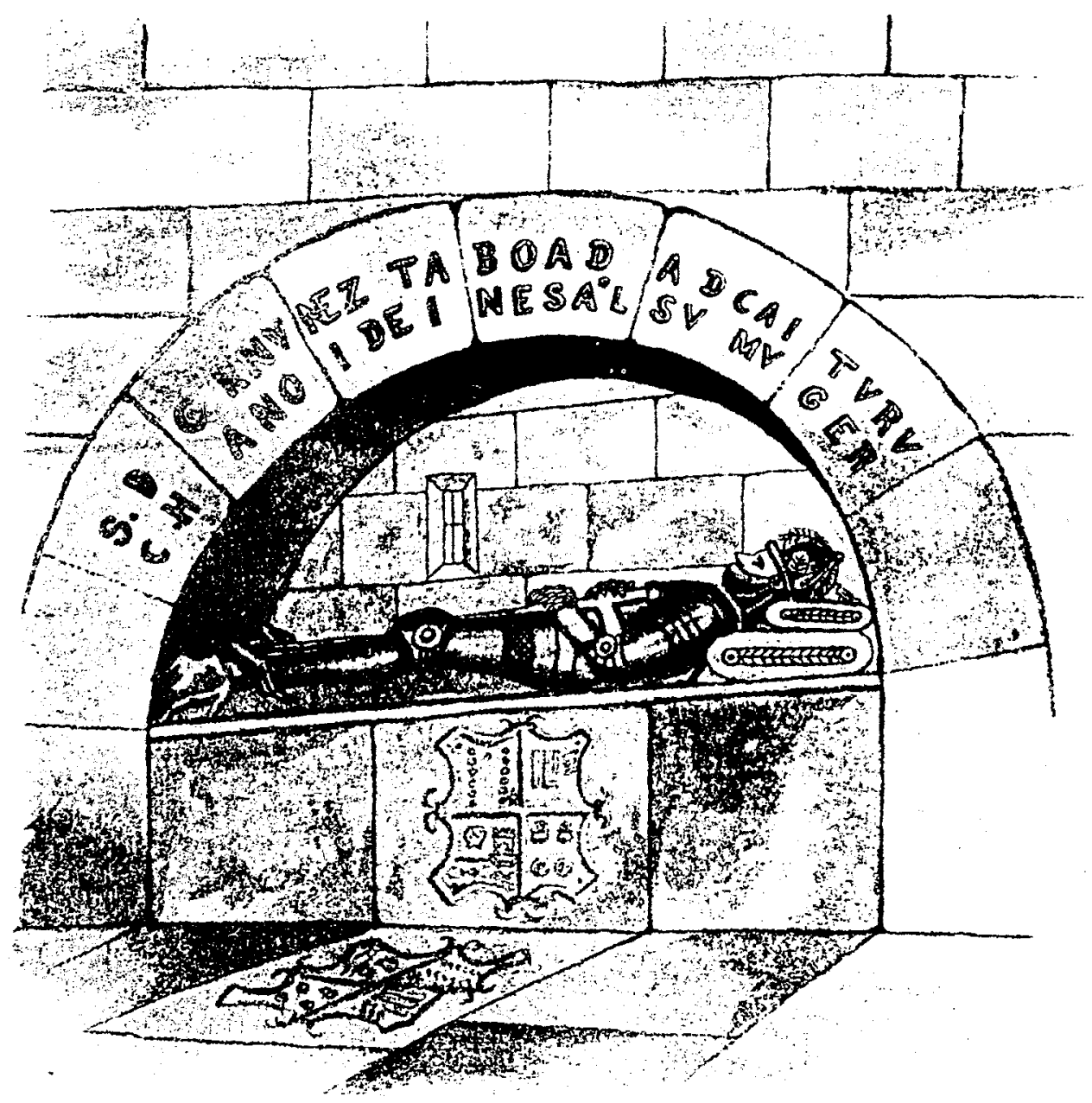

Figura 30. (Museo de Pontevedra).

Unha destas labras sitúase no frontal do monumento, de forma cuadrangular, limitado o seu campo cunha sinxela ornamentación e cuartelada en cruz (Figura 31), coas armas características dos Taboadas de Deza e Churruchaos:

$1^{\circ}$. Trece roeis en tres pales, sinistrados dunha flor de lis.

$2^{\circ}$. Tres táboas sinistradas de tres varas.

$3^{\circ}$. Unha torre almenada sobre ondas nas que nadan dúas troitas, adestrada dunha cuncha de vieira.

$4^{\circ}$. Dúas rodas de carro superadas de dúas caldeiras. 
Particularidades destacables desta labra, as armas dos Churruchaos, nas que se suprime unha cuncha por falta de espacio e, sobre todo, a simplificación que supón a conversión das tres flores de lis que viamos nas pedras armeiras anteriores nunha soa, así como as tres caldeiras en dúas.

En fronte desta labra, nunha lápida no chan, existe outra que semella te-las mesmas armas, pero que non se pode apreciar na súa totalidade por estar sobre ela un confesionario.

Na mesma capela, e na bóveda de crucería, hai varios plafóns armoriados. O central, cuartelado en aspa coas rodas e caldeiros dos Taboada e Camba, e noutros dous unha flor de lis e tres bandas ou barras (Figuras 32, 33 e 34, respectivamente).

Na chamada casa da Calzada, antigamente pazo de Bendoiro, existía unha labra que foi trasladada ó pazo de Anzuxao (Santadrao de Madriñán) (Figura 35). Cuadrangular, en forma de pel apergamiñada, é unha copia das armas reproducidas no sartego de Bendoiro.

\section{Liña de Gonzalo Taboada y Ulloa}

Outro dos fillos de Alonso Núñez de Taboada, señor de Bendoiro, foi Gonzalo Taboada y Ulloa. Era escudeiro, escribán, fidalgo recoñecido e un dos persoeiros máis poderosos de finais do século XVI e comezos do XVII en Deza. Casou con Dominga Fernández de Deza ${ }^{49}$ e constituíu este matrimonio a orixe do pazo de Golmar, en Santa María de Noceda, fundado sobre os bens que ó dito Gonzalo lle deixara o seu pai, incrementados con múltiples adquisicións que realizou ó longo da súa vida.

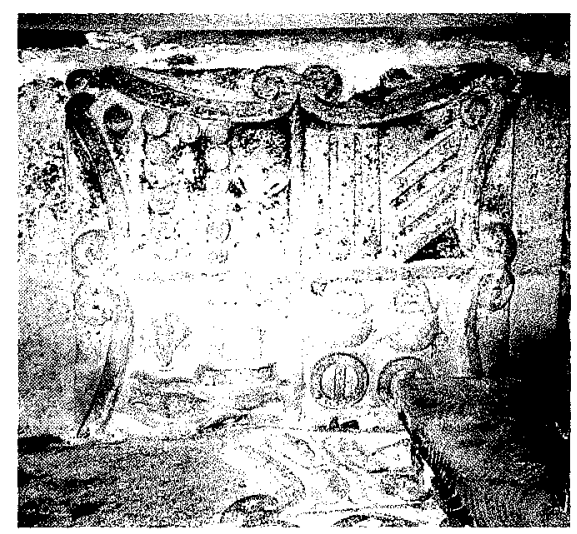

Figura 31 .

${ }^{49}$ Filla do vicario de Deza, restaurador e patrón da capela da Nosa Señora da Cerbaña, Pedro Fernández de Deza. 


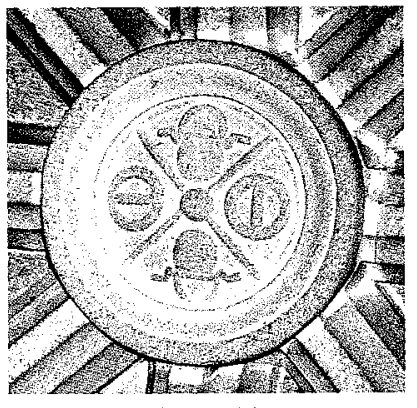

Figura 32.

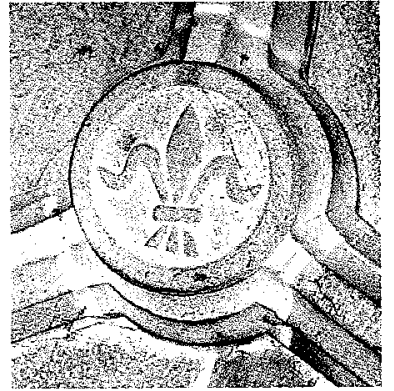

Figura 33.

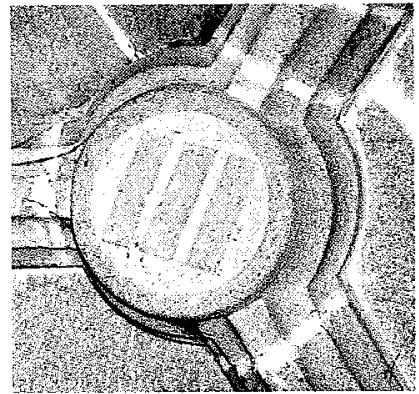

Figura 34.

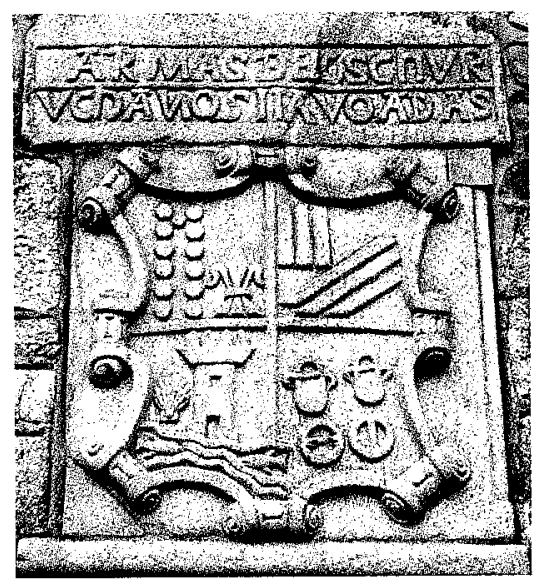

Figura 35.

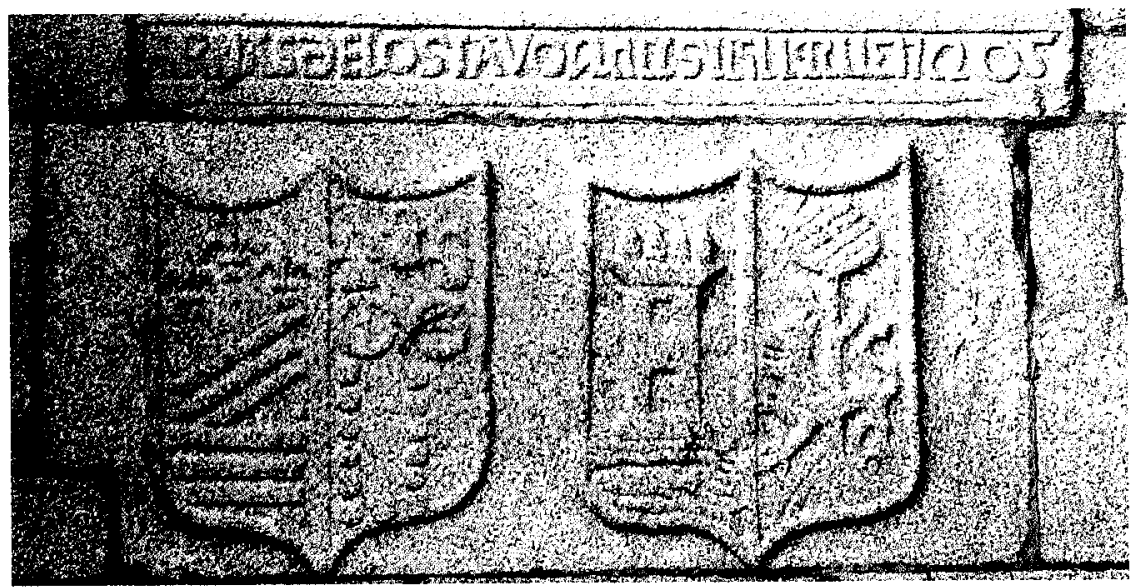

Figura 36.

Cuadernos de Estudios Gallegos, Tomo LII, Fascículo 118, Santiago 2005. (Págs. 389 - 426) 


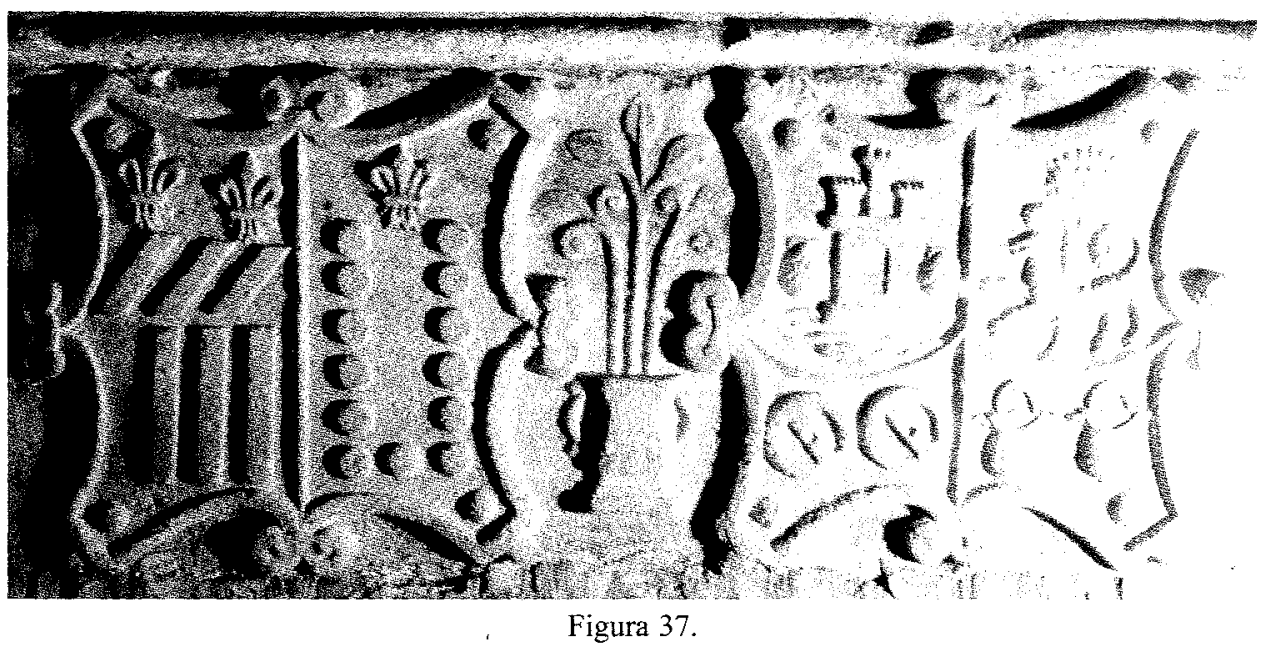

Golmar, chamado antigamente «palacio de Golmar», non ten moitos elementos que recorden este esplendoroso pasado, e un deles é a pedra armeira (Figura 36). Labrados nun só bloque de cantería atopamos dous escudos que representan as armas do matrimonio, superados doutra peza de granito cun epígrafe no que se le: ARMAS DE LOS TAVOADAS I CHURUCHANOS.

A forma dos escudos é antiga, con escotaduras na parte superior e rematados en punta da inferior. Son de finais do século XVI ou comezos do XVII. Ámbolos dous son partidos, representando o da esquerda as armas principais (TABOADA DE DEZA) e o da dereita as secundarias (CHURRUCHAOS e INFANZÓNS DE SOUTOLONGO).

No da destra, no primeiro cuartel trae tres lises, tres barras e tres faixas, e no segundo tres caldeiras, dúas rodas de carro e trece roeis (TABOADA).

O da sinistra, no primeiro cuartel, unha torre almenada sobre ondas e deitada de dúas cunchas de vieira (CHURRUCHAOS). No segundo unha árbore arrincada resaltada dun león pasante (armas do pazo de Soutolongo).

$\mathrm{Na}$ igrexa de Santa María de Noceda fundou o dito Gonzalo Taboada unha capela onde foron enterrados os seus restos ${ }^{50}$, nun monumento baixo arcosolio con estatua xacente. A factura, tanto da escultura coma das labras que se atopan no frontis é moi coidada, e nelas figuran as armas repartidas dun xeito estético (Figura 37).

${ }^{50}$ A data da fundación ou construcción é o 1620 , como testemuña a inscrición gravada na bóveda de crucería. No arcosolio figura a lenda ESTA CAPILLA HIZO I FVNDO GV TAVOADA I VLLOA I LA DOTO D SVS VIENES I MANDO DZIR VNA MISA CADA SEMANA PARA SIENPRE. 
Separados por un floreiro con flores (símbolo mariano), son dúas labras de idéntica factura, cuadrangulares, limitado o seu campo por cintas enlazadas e cun cravo figurado nas esquinas, con función ornamental. As armas son as mesmas das do pazo de Golmar.

A labra da destra é partida:

$1^{\circ}$. Tres táboas superadas de tres barras e estas superadas de dúas flores de lis. $2^{\circ}$. Trece roeis en tres pales, superados de unha flor de lis.

A da sinistra é cuartelada en cruz, coa particularidade de face-la división horizontal cóncava nos cuarteis superiores para permiti-la labra dos mobles que neles se dispoñen.

$1^{\circ}$. Un castelo sobre ondas nas que nada unha troita, deitado de dúas cunchas de vieira.

$2^{\circ}$. Unha árbore arrincada resaltada dun león pasante atado ó seu tronco (é de destacala curiosa forma deste animal, con pretensións artísticas) (Figura 38).

$3^{\circ}$. Dúas rodas de carro.

$4^{\circ}$. Dúas caldeiras en faixa.

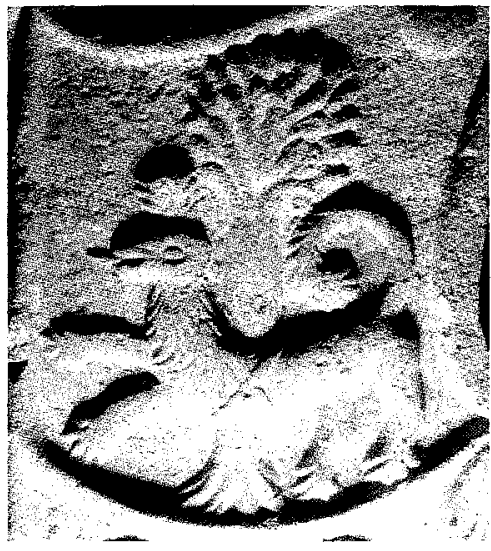

Figura 38.

Así mesmo, na sancristía da mesma igrexa de Noceda, parcialmente oculta con unha placa de cemento ${ }^{51}$, atopamos outra labra da época barroca, moi similar e posiblemente contemporánea da de Bendoiro. Desta pedra armeira coñecemos un debuxo de Enrique Campo que se conserva no Museo de Pontevedra (Figura 39).

É de forma oval, sobre cartela barroca, cuartelado en cruz con escusón, repetindo as mesmas armas que o de Bendoiro, aínda que no escusón si figura un castelo deitado de dúas cunchas de vieira.

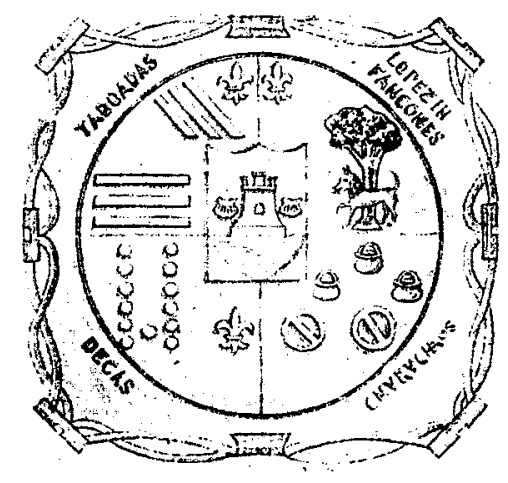

Figura 39.

${ }^{51}$ Queda cuberta pola metade, é dicir, os dous primeiros cuarteis e a metade do escusón. 
$\mathrm{Na}$ cartela figura indicado en cada cuartel o nome da liñaxe á que corresponden as armas, así no primeiro indica TABOADAS, no segundo, LOPEZ IN / FANCONES, no terceiro DECAS e no cuarto CHVRVCHAOS.

Descendentes desta liña de Golmar son tamén os posuidores do pazo de Barrio, en San Xoán de Anzo, hoxe en proceso de restauración e ameazado o seu entorno pola construcción da vía do tren de alta velocidade.

Emprazada no interior do corredor de acceso á planta nobre, a labra heráldica ten forma cuadrangular, redondeada na parte superior e rematada en punta na inferior, rodeada de ornamentación vexetal e en punta unha cabeza de anxo (Figura 40). Cuartelado en cruz, trae as seguintes armas:

$1^{\circ}$. Tres roeis en tres pales $(4-5-4)$.

$2^{\circ}$. Tres flores de lis ben ordenadas e dúas rodas de carro nos cantóns da punta.

$3^{\circ}$. Tres táboas e bordura cargada de oito caldeiras.

$4^{\circ}$. Unha torre donxonada e almenada sobre ondas nas que nadan dúas troitas, deitado de dúas cunchas de vieira nos cantóns do xefe.

Ó timbre helmo adestrado e empenachado.

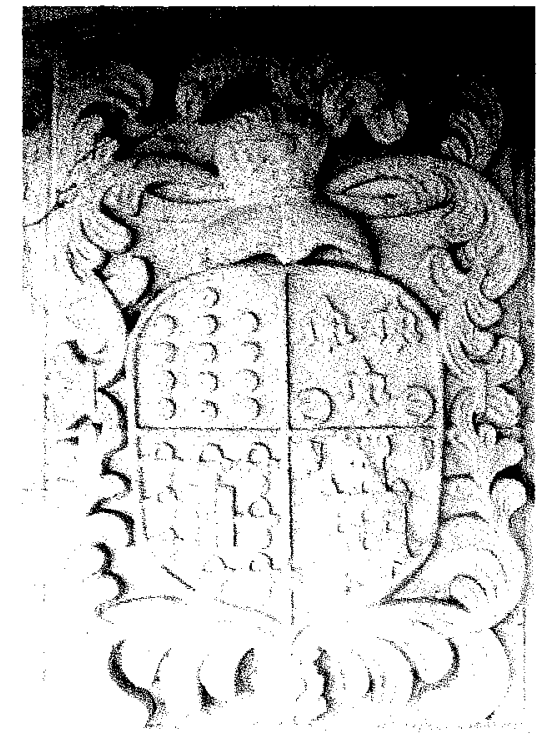

Figura 40.

\section{Liña de Clara Rodríguez de Torres}

Outra filla de Alonso Núñez de Taboada e de Margarida López foi Clara Rodríguez de Torres Taboada. Ímonos centrar, primordialmente nun dos fillos que lle quedaron do seu matrimonio con Pedro do Río, chamado Gonzalo Rodríguez de Torres Taboada, que exerceu como escribán da Súa Maxestade do 1608 ata a súa morte, no 1638 .

Gonzalo foi veciño de Casares, en San Miguel de Goiás, e habitou co seu tío, o párroco de Goiás, Álvaro López Taboada, propietario do citado lugar ${ }^{52}$. Este, no testamento co que faleceu deixou por herdeiros ós seus irmáns, pasando logo ó

\footnotetext{
${ }^{52}$ Era fillo do citado Alonso Núñez de Taboada, primeiro posuidor de Bendoiro.
} 


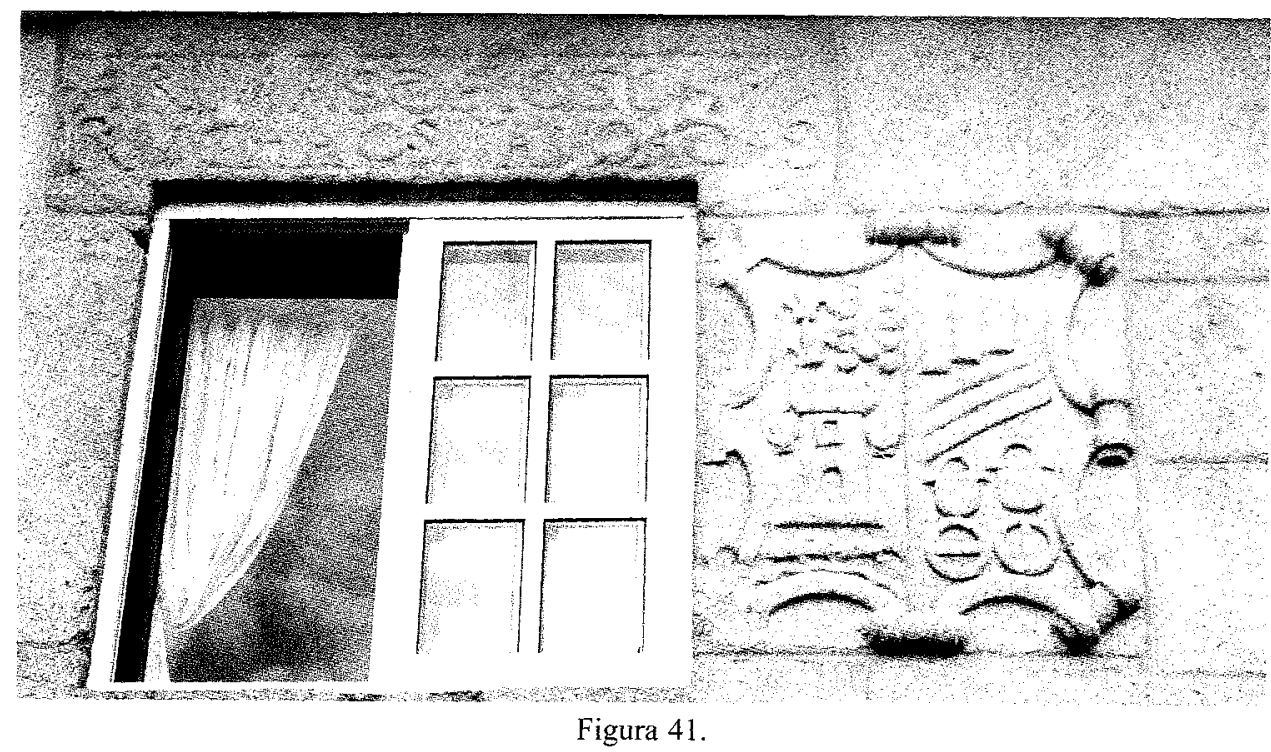

devandito escribán ó casar con Margarita López Taboada, filla de Alonso Saco Taboada, dono de Bendoiro.

$\mathrm{Na}$ casa de Casares consérvase a construcción na que viviron estes fidalgos e, aínda que moi reformada, mantense a grande porta de arco de medio punto e o corredor (hoxe cuberto), perdéndose co paso do tempo a cheminea que tiña antigamente. Tamén na fachada principal aínda se pode olla-la pedra armeira (Figura 41).

Como tantos outros exemplos na comarca de Deza, trátase dunha cartela cuadrangular en forma de pel apergamiñada, o que nos leva a supoñer que data de comezos do século XVII. É partida e trae as seguintes armas:

$1^{\circ}$. Unha torre almenada sobre ondas nas que nadan dúas troitas, deitada de dúas cunchas de vieira, e superada no cantón destro do xefe de dúas flores de lis e no cantón sinistro de trece roeis.

$2^{\circ}$. Do xefe á punta trae: tres táboas, tres barras, dúas caldeiras e dúas rodas de carro.

Á destra a inscrición ARMAS DE LOS CHVRVCHAOS I TAVOADAS.

É de destacar nesta labra a aparición de dúas flores de lis, en vez de tres ou unha, como é habitual. 


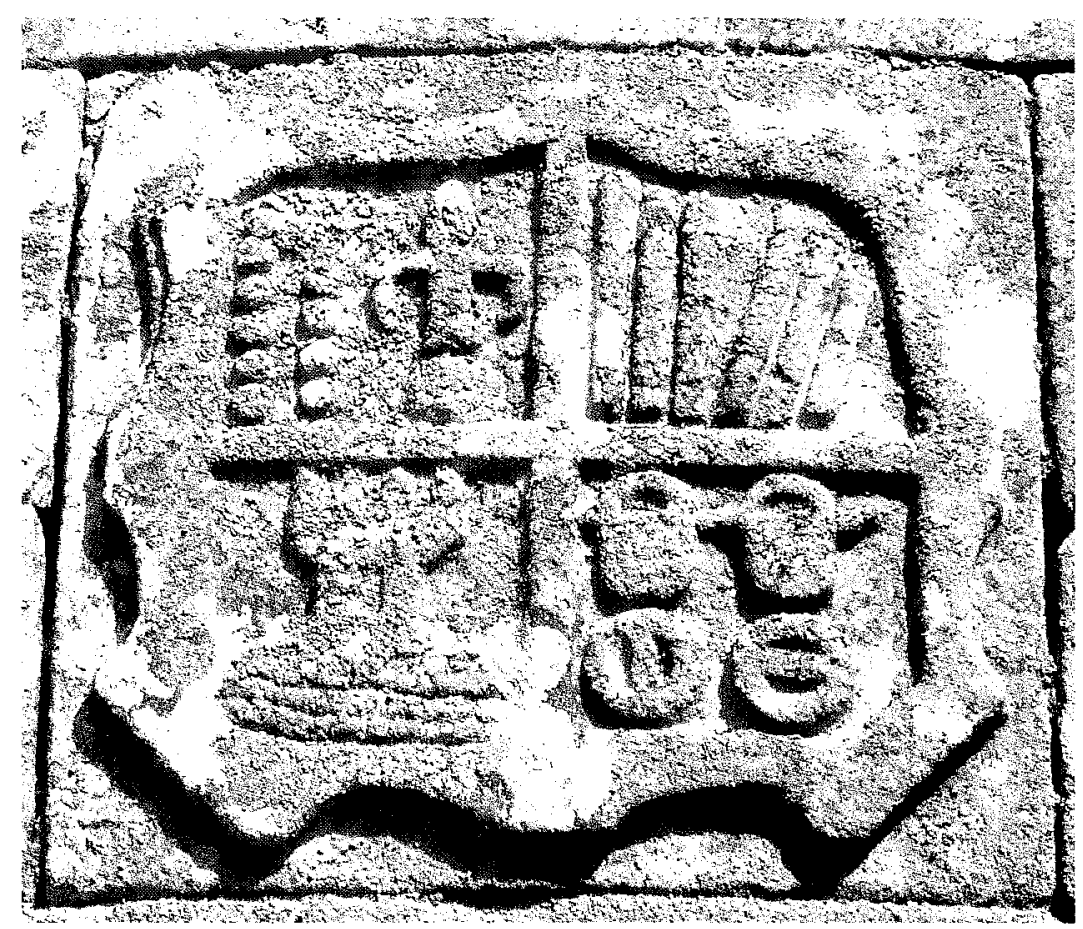

Figura 42.

$\mathrm{Na}$ igrexa parroquial de Goiás, no exterior da capela da casa, consérvase outra pedra de armas, de factura moito máis sinxela (Figura 42). É cuadrangular e o seu campo é cuartelado en cruz:

$1^{\circ}$. Trece roeis en tres pales (6-1-6), sinistrados dunha figura que semella unha cuncha de vieira, superada de unha flor de lis.

$2^{\circ}$. Tres táboas sinistradas de tres barras.

$3^{\circ}$. Unha torre almenada sobre ondas. Alude este cuartel ós Churruchaos, en unión coa vieira do cuartel superior, pero nel non figuran as troitas que adoitan aparecer nas representacións desta liñaxe.

$4^{\circ}$. Dúas rodas en faixa, superada cada unha delas dunha caldeira. 


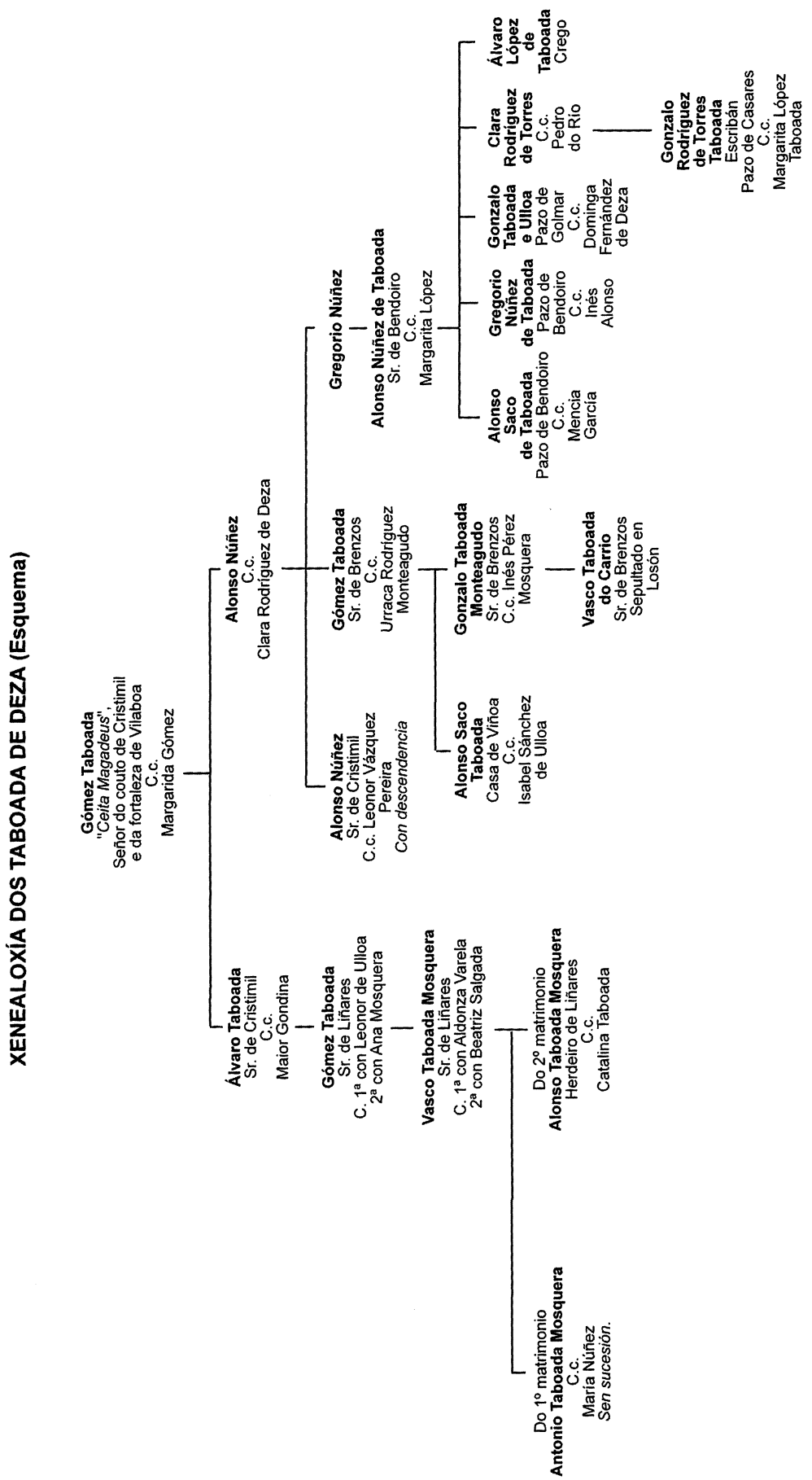

Cuadernos de Estudios Gallegos, Tomo LII, Fascículo 118, Santiago 2005. (Págs. 389 - 426) 


\section{CONCLUSIÓNS}

A historia dos Taboada na comarca de Deza aparece clara desde comezos do século XVI, pero non acontece o mesmo no século XV, no que as imprecisións e a falta de documentación sobre as relacións entre os diversos persoeiros que xorden nesa época na terra dezá non fan doado o estudio desta liñaxe.

Escasos os datos documentais, a elaboración dunha hipótese xenealóxica non tería razón de ser nin base certa. A través da heráldica, en cambio, podemos apreciar unha relación de parentesco ou proximidade con aqueles Taboada e Camba que se enterraron na igrexa de Ferreira de Pallares. A similitude as armerías que figuran, tanto nos enterramentos deste templo, como nalgunha das máis antigas labras da comarca dezá suxiren un coñecemento destas sepulturas por parte dos fidalgos de Deza. Así mesmo, se pode intuír un antigo parentesco cos Varela do que non existe ningunha pegada documental.

Desde o primeiro personaxe do que temos noticias documentais, Gómez Taboada, "Ceita Magadeus», vemos que as súas armas, se van modificando coa súa descendencia en dúas liñas ben diferenciadas, a de Liñares e a de Bendoiro (que engade os emblemas dos Churruchaos).

Créanse en Deza, pois, unhas novas armerías a partir da unión doutras que empregaban as liñaxes das que os Taboada locais afirmaban descender. Estas armas, así incorporadas nun só brasón familiar transmítense e cópianse de xeración en xeración dentro das diversas pólas da familia, ata chegar ó século XVIII, en que que xa se adoptan as formas comunmente aceptadas e recollidas nos nobiliarios como armas propias dos Taboada. 